\title{
The Social Value of Health Insurance: Results from Ghana is
}

\author{
Sílvia Garcia-Mandicó ${ }^{\mathrm{a}, \mathrm{b}}$, Arndt Reichert ${ }^{\mathrm{c}, \mathrm{d}}$, Christoph Strupat ${ }^{\mathrm{e}, *}$ \\ a Directorate of Employment, Labour and Social Affairs, OECD, France \\ ${ }^{\mathrm{b}}$ Erasmus University Rotterdam, The Netherlands \\ ${ }^{\mathrm{c}}$ Leibniz University Hannover, Germany \\ ${ }^{\mathrm{d}}$ Development Impact Evaluation Group, Development Economics Vice-presidency (DEC), World Bank, United States \\ ${ }^{\mathrm{e}}$ German Development Institute/Deutsches Institut für Entwicklungspolitik (DIE), Germany
}

\section{A R T I C L E I N F O}

\section{Article history:}

Received 29 June 2019

Revised 23 September 2020

Accepted 27 September 2020

Available online 19 December 2020

\section{JEL Codes:}

D10

012

I13

Keywords:

Insurance

Social protection

Health shocks

Child labor

Ghana

\begin{abstract}
A B S T R A C T
We use the roll-out of the national health insurance in Ghana to assess the cushioning effect of coverage on the financial consequences of health shocks and resulting changes in coping behaviors. We find a strong reduction in medical expenditures, preventing households from cutting non-food consumption and causing a decrease in the volume of received remittances as well as labor supply of healthy adult household members. Moreover, we present evidence that the insurance scheme reduced the likelihood that households experiencing a health shock pulled their children out of school in order to put them to work. Avoidance of such costly coping mechanisms is potentially an important part of the social value of formal health insurance.

(c) 2020 The Authors. Published by Elsevier B.V. This is an open access article under the CC BY license (http:// creativecommons.org/licenses/by/4.0/).
\end{abstract}

\section{Introduction}

A common view in the literature has been that the value of introducing social insurance can be inferred from the fluctuations in consumption after households experience an income or expenditure shock (Townsend, 1994). If consumption does not fluctuate very much, then the welfare gains from smoothing consumption through social insurance must be small (Morduch, 1995). Contrary

\footnotetext{
We thank Christelle Dumas, Pilar García-Gómez, Simona Helmsmüller, Jacobus de Hoop, Stefan Klonner, Sabine Liebenehm, Owen O'Donnell, Caio Piza, Dan Rogger, Mathis Wagner, one anonymous World Bank Development Impact Evaluation Group staff member, two anonymous reviewers, Monica Singhal, and the participants of the tenth IZA/World Bank Conference on Employment and Development: Technological Change and Jobs, the seminar of the World Bank Development Impact Evaluation Initiative, as well as the Annual Meeting of the Research Group on Development Economics of the German Economic Association. All the views expressed in this paper should be considered those of the authors alone and do not necessarily represent those of the OECD, the German Development Institute, or the World Bank.

* Corresponding author.

E-mail addresses: silvia.garcia-mandico@oecd.org (S. Garcia-Mandicó), arndt. reichert@ihe.uni-hannover.de (A. Reichert), christoph.strupat@die-gdi.de
} (C. Strupat). to this perspective, Chetty and Looney (2006) argue that uninsured households facing shocks could employ strategies to protect (minimum) consumption levels. These strategies are potentially detrimental in the short and long term. This may especially apply to poorer economies, where wealth and access to financial instruments is limited, which can force households to resort to costly means of consumption smoothing. In this case, welfare gains from insurance may actually be very large even though consumption does not fluctuate much.

This paper aims to empirically assess this conceptual point by examining the impact of a national health insurance program in Ghana on basic consumption and reliance on costly strategies to cope with the financial consequences of health shocks. When introducing social insurance, the protection from medical expenditures has been a top priority for many governments in the developing world, which illustrates the relevance of the application examined in this analysis (World Bank, 2014).

There are several empirical studies showing that basic consumption does not always fluctuate with shocks, evidenced by the wide range of reported estimates (e.g., Gertler and Gruber, 2002; Mohanan, 2013). To protect their consumption levels, 
households have been shown to resort to costly self-insurance strategies such as taking out informal loans with high interests (e.g., Khan et al., 2015), selling productive assets (e.g., Rosenzweig and Wolpin, 1993), and removing children from school (e.g., Mitra et al., 2016). Much less empirical evidence is available on the avoidance of costly consumption-smoothing mechanisms when social insurance programs are introduced. Empirical work is limited to either small insurance schemes run by non-profit organisations (e.g., Landmann and Frölich, 2015; Janzen and Carter, 2019), or schemes with partial population and risk coverage (e.g., Liu, 2016). ${ }^{1}$ While reporting encouraging findings, it may not replicate well for government-run insurance schemes aimed to provide broad protection to the population at large. ${ }^{2}$ In fact, there are numerous examples of programs that were scaled up by governments in terms of the number of people covered and program components, but the size of the measured treatment effect differed substantially (AlUbaydli et al., 2017; King et al., 2009; Bagnoli, 2019).

In order to close this gap in the literature, this paper presents causal estimates for the effects of the Ghanaian national health insurance scheme (NHIS), which served as a precedent for many countries of the African continent and, thus, can be found in a similar form elsewhere (Alhassan et al., 2016). ${ }^{3}$ Besides out-of-pocket medical payments and consumption, we examine the effects on the utilisation of various means of consumption-smoothing. These include taking out loans, the reception of remittances, supply of labor by non-sick adult household members, and child labor. Since the latter is likely to adversely affect the childrens' well-being later in life, ${ }^{4}$ it serves as an example of a potentially very costly strategy from a social point of view. Thus, it is indicative of the high value of formal insurance despite small consumption responses.

Our analysis exploits the fact that the staggered implementation of the scheme overlapped with the roll-out of the fifth round of the Ghanaian Living Standards Survey. We are able to observe, within the same district, enumeration areas (EAs) interviewed right before the NHIS introduction, and EAs interviewed right thereafter. This allows us to use a regression discontinuity design with time and district fixed effects, where the running variable measures the months from the NHIS implementation at the district level. Because the timing of interviews of households is external to the timing of the NHIS adoption, we argue that, within the same district, whether a household was observed before or after NHIS implementation is as good as random. We indeed find no system-

\footnotetext{
${ }^{1}$ Landmann and Frölich (2015) report a reduction in child labor in the context of a randomized control trial that paired micro-credit with a micro health and accident insurance in Pakistan. Janzen and Carter (2019) investigate the impacts of an indexbased micro livestock insurance and find a reduction in sales of productive assets among poor households. Liu (2016) examines a large insurance covering mainly inpatient medical treatments in rural China and finds a reduction in the employment of children and an increase in school attendance.

2 More evidence is available on the incentive effects of large insurance schemes in the developing context (e.g. Bergolo and Cruces, 2014; Gerard and Gonzaga, 2016).

3 Edmonds (2006), to our knowledge, is the only study examining the utilization of costly consumption smoothing strategies in response to a large government run program. The author investigates the effect from receiving fully anticipatory social pension income in South Africa. He finds strong improvements in school attendance and child labor when poor households become eligible for social pension. However, the paper's insights about the social value of social insurance is diminished by the fact that, as opposed to the setup characterised in Chetty and Looney (2006), the event resulting in the benefit was fully anticipated and the pension yielded a net increase in income.

4 See Heady (2003),Borga (2019), and Mussa et al. (2019) for the effects of child labor on skill and human capital formation. Dumas (2012) and Keane et al. (2018) show detrimental effects of child labor on cognitive development. Also, children who work early on were found to have lower wages (Emerson and Souza, 2011; Posso, 2017) and a worse health status (Beegle et al., 2009; Sturrock and Hodes, 2016) later in life. Of course, it is not to question that food consumption profiles of children can be important determinants of their future health and education (e.g., Christian and Dillon, 2018).
}

atic discontinuities in the characteristics of households that were interviewed around the time of the NHIS introduction.

We start by showing strong impacts on out-of-pocket medical payments. In specific, we find that the NHIS resulted in a reduction of out-of-pocket payments for medical care of about US\$4, or about $20 \%$ of the mean observed before the program was implemented. This estimate falls in the lower range of previous papers (King et al. (2009); Bauhoff et al. (2011); Limwattananon et al. (2015)). When splitting the sample by the length of a sickness episode, which we show was unaffected by the NHIS, estimation results reveal that out-of-pocket payments decreased by approximately US\$13 for households experiencing more intense sickness episodes. Since we do not find any impact among households with a low sickness intensity, our results for out of pocket payments seem largely driven by households facing intense sickness episodes. Despite the large savings in out-of-pocket payments among the latter, we find limited effects on their consumption. In specific, we observe close to zero responses in food consumption and an increase in non-food consumption of about US\$4.

We then examine the effects on households' means of consumption smoothing. We find that the NHIS crowded out remittances and labor supply of the adults in households facing more intense sickness. Importantly, our results show that the NHIS avoided the use of costly coping strategies among these households. We observe a reduction in child labor and improvements in children's school attendance as result of the introduction of the NHIS.

The remainder of the paper is organized as follows. First, we describe the roll-out of the NHIS in Ghana. Then, we describe the data used and develop our research design. In Section 4, we describe our empirical specification, and Section 5 presents our results and robustness checks. Section 6 concludes.

\section{Institutional background}

The Ghanaian NHIS. In August 2003, the Ghanaian government passed the National Health Insurance Act 650, establishing the terms of the NHIS. The implementation of the insurance was organized at the district level and managed by local authorities, through the establishment of district-wide insurance schemes (DMHIS) (Gajate-Garrido, 2013). Districts capacity to set up DMHIS varied significantly, and while some districts started adopting the NHIS in 2003, the country was fully covered only by October 2007 (see Fig. 1). Generally, districts that had more developed pre-NHIS health care systems adopted the NHIS earlier. ${ }^{5}$

Coverage. The NHIS was implemented to ensure equitable and universal access to health care by removing the financial barriers imposed by user fees. The NHIS health care package covered basic health care services, including inpatient and outpatient consultations, essential drugs, maternity care (normal and cesarean delivery), eye care, dental care, and emergency care. The NHIS package was particularly generous in the range and extent of medicines covered. All DMHIS were required to adhere to the defined benefit package (Gajate-Garrido, 2013).

Premiums. Covered health services were financed through a Health Insurance Levy (a 2.5 percent tax on specific goods and services made in or imported to Ghana), and the payment of insurance

\footnotetext{
5 The capacity of districts to set up DMHIS depended in part on whether (partial) health insurance coverage was already in place. Specifically, existing governmentsponsored Mutual Health Organizations (MHOs), which were organized at the district-level and offered coverage to informal sector workers, were automatically converted to DMHIS (Agyepong and Adjei, 2008). As a result, districts that had a better health care provision system and a higher number of MHOs were able to more easily obtain licenses for the NHIS than districts that needed to build their health care organizations from scratch.
} 


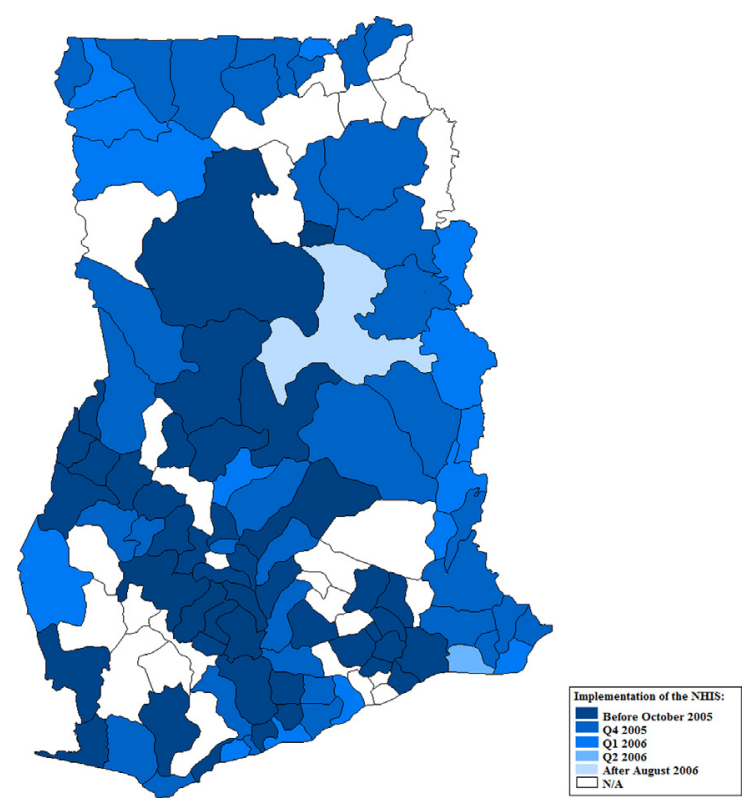

Fig. 1. Spatial Roll-out of the NHIS. Source: own data collection on NHIS implementation date.

premiums. NHIS annual premiums were income-related, set at a minimum of 72,000 Ghana cedis (GHS) per adult (US\$ 7.5), and a maximum of 480,000 GHS (US $\$ 50) .{ }^{67}$ In a typical two-parent family with three children, the entire family would have been covered for 144,000 GHS per year (US $\$ 15$ ). This premium is about 3 percent of the annual minimum wage in 2006 (Otoo et al., 2009). Satisfaction surveys during the first months of its implementation raised the issue of the affordability of its annual premium. This concern was backed up by moderate initial take-up rates of insurance (Sulzbach et al., 2005). However, a comparison of the NHIS premium with MHOs shows the advantages of the NHIS for its enrollees (Sulzbach et al., 2005). For a typical family, the premiums paid under MHOs for inpatient coverage were comparable to those paid under the NHIS for the full coverage package.

Health Care Use. Sulzbach et al. (2005) show that insured individuals sought formal health care sooner after the onset of illness than their uninsured counterparts. Greater coverage from the NHIS also induced behavior consistent with moral hazard. Debpuur et al. (2015) highlight numerous ways in which the insured took advantage of the NHIS, such as frequent and unnecessary visits to health facilities, impersonation, or even feigning sickness to collect drugs for non-insured persons.

\section{Data and research design}

\subsection{Data}

The purpose of this paper is to identify the impact of public health insurance on households' out-of-pocket spending and the incidence of informal insurance mechanisms used to cope with these expenditures and other financial consequences of health shocks. To analyze these effects, we use household data from the fifth round of the Ghana Living Standards Survey (GLSS), collected from October 2005 to September 2006. The fifth round of the GLSS interviewed 37,128 individuals in 8,687 households.

\footnotetext{
${ }^{6}$ In 2007 , the exchange rate was 9,600 GHS to US $\$ 1$.

7 Formal sector employees paid their premiums on a monthly basis, while members of the informal sector had to pay annual premiums.
}

Because the timing of implementation of the NHIS across districts is not random, our empirical strategy relies on within district variation as opposed to cross-district variation. Correctly identifying geographic information is therefore central to our analysis. The finest within-district level reported in the survey is the enumeration area (EA), which roughly corresponds to villages (in rural areas) and neighborhoods (in urban areas). EAs within the same district were surveyed at different times, with no systematic order. Importantly, the date of the survey of each EA is orthogonal to key defining characteristics, such as population, economy, infrastructure, provision of education, and health care facilities. ${ }^{8}$ This orthogonality is key for the identification of the impact of the NHIS, as we will explain below.

We link the GLSS data to information on the exact implementation date of the NHIS at the district level. We collected these data from several sources, ranging from district level NHIS web-pages to newspaper articles and phone calls to district level NHIS authorities. ${ }^{9}$ Fig. 1 shows the map of Ghana's 110 districts, colored by date of adoption of the NHIS. Some districts adopted the NHIS as early as January 2003 as part of a pilot. By January 2005 it became a national policy, and local authorities consistently started adopting the NHIS. By October 2007, all local authorities had successfully introduced the NHIS in their districts. During the period of the survey, 53 districts adopted the NHIS. Of these, 52 districts had at least one EA surveyed before and one after the adoption of the NHIS. We only keep households in such districts, to ensure that there is within-district variation, resulting in a final sample of 28,946 individuals in 5341 households.

We construct variables measuring household out-of-pocket medical expenditures, consumption, loans and remittances received, adult labor supply, as well as child labor (following the ILO definition), and time allocation (school attendance and household chores). ${ }^{10}$ We refer to Tables A.1 and A.2 in Appendix A for more details on the construction of these variables. Means of all outcome variables for the pre-NHIS period are reported jointly with the estimates of our empirical analysis in Section 5.

\subsection{Research design}

In an ideal experiment, one would randomly grant NHIS access to districts and compare household responses to health shocks in districts with access to the NHIS to the counterfactual behavior of ex-ante similar households in districts without access to the NHIS. Absent this, we obtain within district variation by exploiting the fact that the NHIS was rolled out simultaneously to the fifth round of the GLSS in some districts.

We construct $d$, a measure of the months between the date of interview and the NHIS implementation date in the district of residence. Setting the date the district adopted the NHIS to zero, the survey contains households from EAs interviewed at $d<0$, and households from EAs interviewed at $d \geqslant 0$. By keeping only these districts having both negative and positive (or zero) values of $d$, we can exploit the within-district variation in the timing of the survey. If within each district, timing is truly orthogonal to EA characteristics, within-district variation in exposure to the NHIS at the time of the survey is as good as random. In this case, EAs interviewed before the NHIS implementation in the district repre-

\footnotetext{
${ }^{8}$ Regressing the date of the interview on a wide range of EA characteristics yields mostly insignificant point estimates.

${ }^{9}$ We were unable to find information on the exact implementation date for 18 districts of the 110. We drop observations from these districts.

${ }^{10}$ One costly coping strategy that has been discussed in the literature is selling of assets and land (Rosenzweig and Wolpin (1993)). Unfortunately, we are not able to examine these indicators because our data captures only asset and land sales over the previous 12 months, which does not fit to our empirical strategy.
} 
sent suitable controls for EAs interviewed after the NHIS was available in the district. This measure $d$ is the running variable of our regression discontinuity $(\mathrm{RD})$ design, which is presented in detail in Section 4.

Our research design captures the reduced-form short-term impact estimates of the reform, where the first stage corresponds to the impact of the NHIS rollout on the health insurance take-up of households. Our data do not allow us to correctly identify changes in health insurance coverage due to the implementation of the NHIS. We can, however, rely on reported national enrollment rates to get an impression of the extent of NHIS coverage. Fig. A.1 of Appendix A shows that national enrollment in 2006 was around 20 percent, and increased to almost 40 percent in 2007. These figures, however, are low bounds of the real coverage rate of the NHIS, as households were frequently allowed to enroll under the NHIS after the occurrence of a health shock (Gajate-Garrido, 2013).

\section{Empirical specification}

For each outcome variable, we estimate the following regression:

$$
\begin{aligned}
Y_{h t s}= & \beta_{0}+\beta_{1} f\left(d_{h t s}\right)+\theta N H I S_{h t s}+\beta_{2} h\left(d_{h t s}\right) N H I S_{h t s}+\delta X_{h t s}+\mu_{s} \\
& +\gamma_{t}+\varepsilon_{h t s}
\end{aligned}
$$

where $d$ is the months separating the date of the interview $t$ for a given household $h$ and the date of NHIS implementation in the district s. NHIS $S_{\text {ts }}$ is a variable taking value 1 if $d \geqslant 0$, and 0 if $d<0$. X is a vector of pre-determined characteristics, ${ }^{11} \mu_{s}$ and $\gamma_{t}$ are district and time fixed effects, and $\varepsilon$ is the error term. We allow the polynomial to differ from the left to the right of the month of NHIS implementation. $\theta$ is the coefficient of interest, and it captures the effect of NHIS implementation at the district level on household responses. $f($.) and $h($.) are some polynomial expansions in $d$. Because of the small number of observations, there is not enough variation to allow both functions to vary non-linearly. We impose in what follows that $f($.) and $h($.) are two different linear trends before and after NHIS implementation, acknowledging that this may represent a limitation for some of the outcome variables.

We determine the optimal bandwidth to the left and right of the discontinuity of $d$ using the bandwidth selector method provided by Calonico et al. (2016). We choose to estimate the model with a bandwidth of 6 months which is the optimal bandwidth for the majority of our outcome variables. ${ }^{12}$ This comes with two important advantages in our context. First, being the largest among all outcome specific optimal bandwidths, it implies a relatively large sample size (3,718 households) and, thus, relatively precise estimates. Second, one bandwidth for all outcomes ensures consistency in the number of observations which improves the interpretation of results (e.g., decomposing the effects on medical spending into consumption responses and other means of insurance). We show the robustness of our results to other outcome-specific optimal bandwidths in Section 5.3.

Following Kolesár and Rothe (2018), we cluster standard errors by the level of treatment assignment. In our context, treatment depends on the combination of the date of implementation of the NHIS (at the district level) and the date of survey (at the EA level). Thus, treatment assignment takes place at the EA level, which determines whether a household is observed before or after

\footnotetext{
11 We include as control variables the age and gender of the head of the household, educational attainment of parents, household composition, an indicator for rural, poor and migrant households, and sector of employment of the head.

12 Exceptions are the rate of remittances, household chores, school attendance (all 5 months), outpatient expenditures, food consumption, and loan amount (all 4 months).
}

the introduction of the NHIS. We therefore cluster the standard errors by EA, and are confident that the number of clusters (520 EAs) is sufficiently large for cluster-robust inference (Cameron and Miller, 2015). We show that inference is robust to cluster choice in Section 5.3.

Threats to Identification. The validity of our research design requires the counterfactual outcome being orthogonal to the date of implementation relative to the interview date. That is, in the absence of the NHIS, households at the left and right of the discontinuity in the assignment variable would have fared the same.

To present support for the assumption of no underlying selection on either side of the discontinuity, we perform several empirical balancing tests. ${ }^{13}$ To test the balancing of characteristics on both sides of the discontinuity, we assess whether the sample averages of household characteristics are similar in the samples before and after NHIS implementation. We select characteristics that, a priori, should not be affected by the NHIS introduction such as household composition, the main source of household income, and education of adult household members. Columns (1), (2) and (3) in Table 1 demonstrate that household characteristics are similar in both samples. We note that in the sample after the introduction of the NHIS the share of fathers living in the household is lower, and the share of mother without a formal education higher. ${ }^{14}$ These differences, however, do not translate into poorer households and other household characteristics, nor in differences in sector of employment.

We also estimate specification (1) using the pre-determined household characteristics as dependent variables. Column (4) of Table 1 shows a marginally significant discontinuity around the cutoff for the share of formal sector employees, but no other significant differences. Given the balancing results, we are confident that the households before and after the discontinuity are comparable. $^{15}$

Analysis by Health Shock. To gain more intuition on the effects of the NHIS, we assess how much these vary by health shock intensity. We expect that households experiencing more severe health shocks respond most to the introduction of the NHIS, for two reasons. First, the savings in out-of-pocket payments of insured households are most likely larger among these households (Liu, 2016). Second, because households can enroll with the NHIS after a health shock occurs (Gajate-Garrido, 2013), the enrollment rate among households reporting more intense sickness is possibly larger. Since our main specification allows recovering the reduced form effects from the NHIS, but not the effect for insured households, observing stronger effects on these households experiencing relatively strong health shock is in line with the effects being driven by the NHIS.

We perform this analysis by splitting the sample using a health shock measure that we construct based on the self-reported number of days of sickness over the two weeks before the interview. Specifically, we define our health shock measure as the ratio of the weighted sum of the days that every adult in the household has reported being ill over the two weeks before the interview, by the period of reference ( 14 days). That is:

$H S_{h t s}=\frac{\sum_{i=1}^{I} a_{i h t s}}{14 n_{h}}$,

\footnotetext{
${ }^{13}$ Although manipulation of the running variable is not a potential issue in this setup, we run a McCrary (2008) density test. We do not reject the null hypothesis of a smooth density around the time of exposure to the NHIS ( $p$-value $=0.18$ ).

${ }^{14}$ We control for these characteristics in our empirical specification, and show in the sensitivity section that the results are not affected by the inclusion or exclusion of these controls.

15 Yet, data six months away from NHIS introduction are systematically different from data just around the date of the introduction, highlighting the need for inclusion of $f($.$) and h($.$) in the regression equation.$
} 
Table 1

Balancing Test of Means Around the Months of Exposure to the NHIS.

\begin{tabular}{|c|c|c|c|c|}
\hline & \multicolumn{2}{|c|}{ Sample of analysis } & \multirow{2}{*}{$\begin{array}{c}\text { Test of equal means } \\
p \text {-value } \\
(3)\end{array}$} & \multirow{2}{*}{$\begin{array}{r}\text { RD tes } \\
(4)\end{array}$} \\
\hline & $\begin{array}{c}d \in[-6 ; 0) \\
(1)\end{array}$ & $\begin{array}{c}d \in[0 ; 6] \\
(2)\end{array}$ & & \\
\hline Rural household & $\begin{array}{l}0.676 \\
(0.468)\end{array}$ & $\begin{array}{l}0.689 \\
(0.463)\end{array}$ & 0.483 & $\begin{array}{l}0.115 \\
(0.192)\end{array}$ \\
\hline Poor & $\begin{array}{l}0.268 \\
(0.443)\end{array}$ & $\begin{array}{l}0.296 \\
(0.457)\end{array}$ & 0.110 & $\begin{array}{l}0.118 \\
(0.114)\end{array}$ \\
\hline Household size & $\begin{array}{l}4.723 \\
(2.925)\end{array}$ & $\begin{array}{l}4.590 \\
(2.835)\end{array}$ & 0.294 & $\begin{array}{l}0.704 \\
(1.410)\end{array}$ \\
\hline Father in household & $\begin{array}{l}0.588 \\
(0.493)\end{array}$ & $\begin{array}{l}0.554 \\
(0.497)\end{array}$ & 0.091 & $\begin{array}{l}0.035 \\
(0.064)\end{array}$ \\
\hline Married or cohabiting & $\begin{array}{l}0.768 \\
(0.423)\end{array}$ & $\begin{array}{l}0.743 \\
(0.437)\end{array}$ & 0.130 & $\begin{array}{l}0.027 \\
(0.035)\end{array}$ \\
\hline Age head & $\begin{array}{l}44.915 \\
(14.100)\end{array}$ & $\begin{array}{l}44.846 \\
(14.926)\end{array}$ & 0.903 & $\begin{array}{l}-2.067 \\
(2.079)\end{array}$ \\
\hline Number of children in household & $\begin{array}{l}1.421 \\
(1.625)\end{array}$ & $\begin{array}{l}1.332 \\
(1.488)\end{array}$ & 0.141 & $\begin{array}{r}-0.018 \\
(0.695)\end{array}$ \\
\hline Formal sector (paid worker) & $\begin{array}{l}0.052 \\
(0.222)\end{array}$ & $\begin{array}{l}0.054 \\
(0.226)\end{array}$ & 0.803 & $\begin{array}{l}0.037 * \\
(0.021)\end{array}$ \\
\hline Informal sector (paid worker) & $\begin{array}{l}0.057 \\
(0.232)\end{array}$ & $\begin{array}{l}0.068 \\
(0.251)\end{array}$ & 0.267 & $\begin{array}{l}-0.052 \\
(0.065)\end{array}$ \\
\hline Own business & $\begin{array}{l}0.231 \\
(0.422)\end{array}$ & $\begin{array}{l}0.248 \\
(0.432)\end{array}$ & 0.322 & $\begin{array}{l}-0.117 \\
(0.078)\end{array}$ \\
\hline Not working & $\begin{array}{l}0.031 \\
(0.173)\end{array}$ & $\begin{array}{l}0.035 \\
(0.183)\end{array}$ & 0.570 & $\begin{array}{l}-0.023 \\
(0.014)\end{array}$ \\
\hline Born in village & $\begin{array}{l}0.607 \\
(0.489)\end{array}$ & $\begin{array}{l}0.578 \\
(0.494)\end{array}$ & 0.117 & $\begin{array}{l}-0.012 \\
(0.064)\end{array}$ \\
\hline No education (father) & $\begin{array}{l}0.554 \\
(0.496)\end{array}$ & $\begin{array}{l}0.594 \\
(0.491)\end{array}$ & 0.129 & $\begin{array}{l}-0.030 \\
(0.019)\end{array}$ \\
\hline Some school (father) & $\begin{array}{l}0.186 \\
(0.389)\end{array}$ & $\begin{array}{l}0.167 \\
(0.373)\end{array}$ & 0.176 & $\begin{array}{l}0.004 \\
(0.024)\end{array}$ \\
\hline No education (mother) & $\begin{array}{l}0.243 \\
(0.429)\end{array}$ & $\begin{array}{l}0.273 \\
(0.446)\end{array}$ & 0.075 & $\begin{array}{l}0.001 \\
(0.012)\end{array}$ \\
\hline Some school (mother) & $\begin{array}{l}0.156 \\
(0.363)\end{array}$ & $\begin{array}{l}0.136 \\
(0.343)\end{array}$ & 0.121 & $\begin{array}{l}0.013 \\
(0.031)\end{array}$ \\
\hline HS ratio & $\begin{array}{l}0.162 \\
(0.099)\end{array}$ & $\begin{array}{l}0.158 \\
(0.111)\end{array}$ & 0.634 & $\begin{array}{c}-0.004 \\
(0.010)\end{array}$ \\
\hline High sickness intensity & $\begin{array}{l}0.412 \\
(0.134)\end{array}$ & $\begin{array}{l}0.487 \\
(0.145)\end{array}$ & 0.345 & $\begin{array}{l}0.087 \\
(0.099)\end{array}$ \\
\hline Households & 1,200 & 2,518 & & 3,718 \\
\hline
\end{tabular}

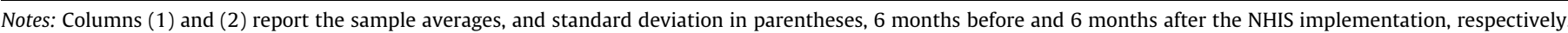

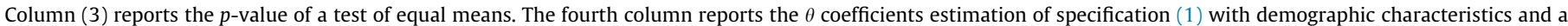
health shock measure as the dependent variables. Standard errors, clustered by enumeration areas, are in parenthesis.

where $a$ are the days individual $i$ from household $h$ has reported being ill or injured over the two weeks before the interview, and $n_{h}$ is the number of individuals in household $h$.

We use HS to divide households with at least one day of sickness into low and high intensity of sickness, according to whether $H S$ is below or above the median. This maximises the sample size of the low and high intensity samples. Among households reporting an illness or injury, the median of this sickness intensity measure is 0.1 . That is, for the median household, 10 percent of the days in the last two weeks were lost to illness. Low sickness households, therefore, are households which reported that they were less than 10 percent of the days in the last two weeks ill.

By distinguishing households according to the intensity of health shock as opposed to whether a health shock is reported at all, we aim to solve the potential endogeneity problem that the incidence of health shocks are reported more often after the introduction of the NHIS. ${ }^{16}$ The intensity of the health shock is unrelated to the introduction of the NHIS if households correctly report the

\footnotetext{
${ }^{16}$ We find that $56 \%$ of households reported a health shock before the NHIS. This figure increases to $61 \%$ of households after the NHIS. This is because households tend to report more often an episode of sickness if they sought health care than if they did not (Murray, 1996). Since the insurance coverage increases the propensity to seek health care, and individuals recall better sickness periods when they have sought care, reporting health shocks is positively correlated to the introduction of the NHIS.
}

number of sickness days once they remember a sickness episode. To verify that, we estimate specification (1) using HS as dependent variable. By construction of this variable, the estimation sample only includes households that report any illness episode. The second last row of Table 1 reports the results. We observe no statistically significant effect of the introduction of the NHIS. ${ }^{17}$ This result makes us confident to split the sample using this variable.

\section{Results}

This section documents the effect of the introduction of the NHIS on medical expenditures and consumption using a RD design. It then moves on to exploring how a national health insurance policy can affect risk-coping mechanisms, with a particular focus on costly coping mechanisms.

One of the advantages of RD designs is that results can be presented graphically, which provides a transparent way of showing how the effects from introduction a national public health insurance is identified. Throughout the paper, we will begin with a

\footnotetext{
17 Panel A of Fig. B.1 in the Appendix shows the RD graphs for this health shock measure. Consistent with the results presented in Table 1, we do not find any discontinuity from crossing the cutoff. The same applies for a binary variable indicating a high sickness intensity (see last row of Table 1 and Panel P of Fig. B.1 in the Appendix).
} 
graphical depiction of key outcomes before turning to a more detailed regression-based analysis. Given our empirical model considers district and time fixed effects, we plot the residuals from a regression of the outcome of interest in order to net out time and district fixed effects. The residualized outcomes are aggregated in bins by months to NHIS implementation, around nine months of the introduction month of the NHIS. ${ }^{18}$ The figures include separate fitted linear trends on each side of the cutoff estimated, and a triangular Kernel-weighted local polynomial fit. ${ }^{19}$ The fitted lines best illustrate the trends in the data and the size of the jump, whereas the binned means provide a sense of the underlying variability in the data. Confidence intervals are constructed on the linear fit, with errors clustered at the enumeration area level (corresponding to the treatment assignment level).

\subsection{The introduction of the NHIS on household expenditures}

\subsubsection{Medical payments}

Panel A of Fig. 2 displays the relationship between the introduction of the NHIS and medical out-of-pocket payments. Medical out-of-pocket payments are the sum of inpatient, outpatient and medicine payments. The expenditures are measured in $\mathrm{x} 10,000$ Gahanian Cedis (GHS), which was slightly more than US\$1 in $2005 / 2006$. The graph reveals that medical payments are constant in the months leading up to the implementation of the NHIS, which is reassuring to the fact that there are no pre-trends once differences between the districts are taken into account. ${ }^{20}$ More importantly, there is a sharp drop in payments for individuals just to the right of the cutoff. ${ }^{21}$ Payments decline in the months after the implementation, which is in line with a greater usage and enrolment to the NHIS. The discontinuity and declining trend are also captured by a triangular-weighted polynomial fit on the full width of the data. Here, the measured drop is even slightly larger than with a linear fit.

We show the RD graphs for inpatient, outpatient and medicine payment separately in Fig. B.2 in Appendix B. They reveal that the drop in medical out-of-pocket payments is due to savings in medicine payments and not due to a reduction in inpatient or outpatient care.

In the first panel of Table 2, we present regression results. The first row of the table displays the results for medical out-ofpocket payments which mirror those displayed in Fig. 2, Column (2) shows that there is a 38,300 GHS (US\$4) drop in payments after the implementation of the NHIS, which amounts to a $20 \%$ reduction compared to the mean (see Column (1)). To give a perspective of the magnitude of the effect, the average monthly NHIS premium is about US\$1.25 per household, so net savings are large. Medicine expenditures are most affected by the introduction of the NHIS. We observe a drop in 28,400 GHS (US $\$ 3$, or $23 \%$ of the mean). Inpatient out-of-pocket payments, which were already covered by district insurances before the introduction of the NHIS, are not significantly affected. Neither are outpatient expenditures.

As $25 \%$ of households in our sample did not incur any medical out-of-pocket expenditures, the medical variables are highly

\footnotetext{
18 This is the widest bandwidth that our data allows for without any gaps.

19 The local polynomial regression involves fitting the response to a polynomial form of the regressor via locally weighted least squares, and the choice of a triangular Kernel allows giving more weight to observations closer to the discontinuity.

${ }^{20}$ In our sample, seven households were interviewed during the first two weeks of the month when their month of interview corresponded to the time of NHIS implementation. This implies that they could have had medical expenditures before the NHIS while being classified as under the NHIS. Our results are fully robust to their exclusion.

${ }^{21}$ Our empirical strategy could be underestimating the impact of the introduction of the NHIS if households delay their medical expenditures in expectation to the introduction of the NHIS. If there was anticipation, we might see a dip in payments in the months right before the NHIS. Panel A indicates that this does not seem to be the case.
}

skewed to the left. These may be more appropriately estimated after applying a logarithmic transformation $(\ln (x+1))$. Column (3) of Table 2 summarizes the results. Using this specification, we estimate a reduction of $17 \%$ in medical out-of-pocket payments, which is similar to respective estimates when using levels.

Columns (4) to (9) in Table 2 present the results after dividing the sample for these households with less and more sickness, based on the health shock intensity measure previously described. They indicate that the effects observed in the full sample are driven by the sample with higher sickness intensity. ${ }^{22}$ Hence, the introduction of the NHIS resulted in higher savings in medical out-ofpocket payments for households experiencing a relatively large health shock. These households saw their medical expenses reduced by 119,800 GHS (US $\$ 13$, or $30 \%$ of the mean) after the introduction of the NHIS. This effect is again driven by a reduction in medicine payment of about $50 \%$.

We also present results on the probability of experiencing catastrophic health care expenditures in Panel A2 of Table 2. As it is standard in the literature, we measure the incidence of catastrophic health care expenditures through an indicator taking value 1 when health care expenditures represent 10 percent or more of the total household expenditure (Cylus et al., 2018; Wagstaff et al., 2018). ${ }^{23}$ In line with the results presented for medical expenditures in levels and logarithms, the effects are driven by the sample experiencing more sickness. For these households, we observe a reduction of 11 percentage points (15\%) in the probability of incurring in catastrophic health care expenditures.

\subsubsection{Consumption}

Panel B in Fig. 2 presents RD graphs for consumption measure, which measures the sum of food and non-food frequent consumption, and excludes health care components (see Appendix A for more details). The fitted lines show that consumption is higher in the months right after the introduction of the NHIS (although marginally insignificant). Panel B in Fig. B.2 of Appendix B shows results for the two components of consumption. The introduction of the NHIS only affected non-food expenditures.

Turing to the regression results, Panel B1 of Table 2 shows a positive estimate on consumption from the introduction of the NHIS, which is statistical significant after the $\ln (x+1)$ transformation. When disaggregating the components of consumption, we find that the introduction of the NHIS led to marginally higher non-food consumption (housing, utilities, transportation, etc.) by 27,500 GHS (US\$3), or $6 \%$ of the mean. Food consumption, which represents the biggest share of consumption, is not affected by the NHIS.

Focusing on the more sickness sample, we do not find effects of the NHIS on food consumption but an increase in non-food consumption by GHS 33,800 (US $\$ 4$, or $9 \%$ of the mean). These results suggest that, in the absence of health insurance, non-food expenditures must have absorbed more of the health shock in order for food consumption levels to remain unchanged (Skoufias and Quisumbing, 2005).

We discreticize consumption and use the official consumption poverty line of the Ghanaian Statistical Service set at $44.9 \%$ of the mean consumption in 2005/2006 (Ghana, 2018). We measure the incidence of consumption poverty by using an indicator taking value 1 when the household consumes more than the consumption

\footnotetext{
${ }^{22}$ Using the full sample, we check whether the propensity of having a highly intense illness episode changed due to the NHIS implementation (the reference category includes households with either a relatively short or no sickness episode at all). We do not find any statistically significant effect of the NHIS on this variable (results are available upon request).

${ }^{23}$ This measure is the official indicator for monitoring of financial protection among
} the Sustainable Development Goals (SDGs; indicator 3.8.2). 
A. Medical out-of-pocket payments

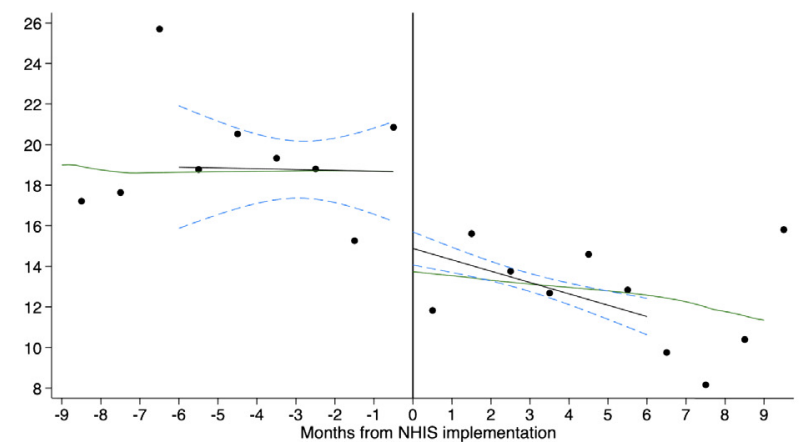

B. Consumption

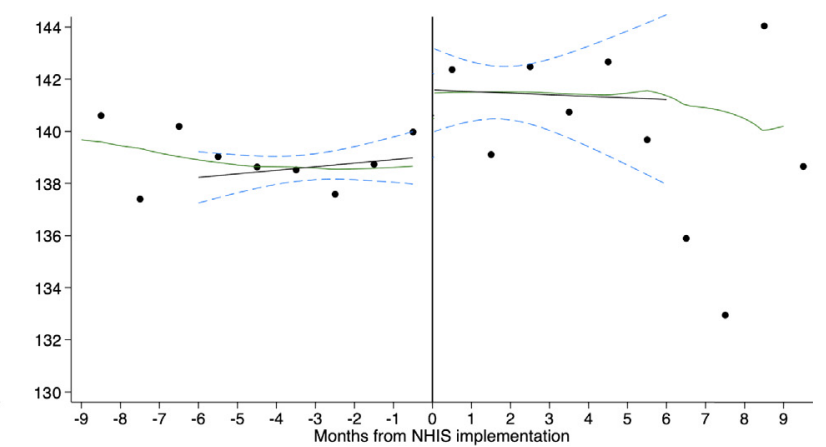

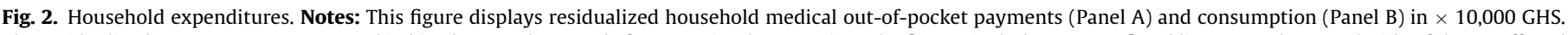

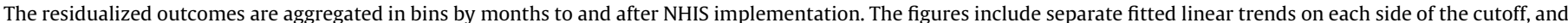

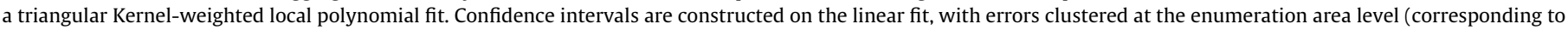
the treatment assignment level)..

Table 2

$\mathrm{RD}$ estimates effects of NHIS introduction on household expenditures.

\begin{tabular}{|c|c|c|c|c|c|c|c|c|c|}
\hline & \multicolumn{3}{|c|}{ Full Sample } & \multicolumn{3}{|c|}{ Less Sickness } & \multicolumn{3}{|c|}{ More Sickness } \\
\hline & Mean & Level & Logarithm $\log (x+1)$ & Mean & Level & Logarithm $\log (x+1)$ & Mean & Level & Logarithm $\log (x+1)$ \\
\hline & (1) & $(2)$ & (3) & (4) & (5) & (6) & (7) & (8) & (9) \\
\hline \multicolumn{10}{|c|}{ A.1 Medical expenditures } \\
\hline Total & 18.74 & $\begin{array}{l}-3.83^{* *} \\
(1.83)\end{array}$ & $\begin{array}{l}-16.77^{* *} \\
(8.04)\end{array}$ & 27.61 & $\begin{array}{l}-3.79 \\
(2.94)\end{array}$ & $\begin{array}{l}-5.87 \\
(4.60)\end{array}$ & 39.96 & $\begin{array}{l}-11.98^{* *} \\
(5.55)\end{array}$ & $\begin{array}{l}-29.20^{*} \\
(16.36)\end{array}$ \\
\hline Inpatient & 0.03 & $\begin{array}{l}0.01 \\
(0.02)\end{array}$ & $\begin{array}{c}-0.21 \\
(0.27)\end{array}$ & 0.03 & $\begin{array}{l}0.00 \\
(0.01)\end{array}$ & $\begin{array}{l}-0.03 \\
(0.14)\end{array}$ & 0.08 & $\begin{array}{l}0.07 \\
(0.11)\end{array}$ & $\begin{array}{l}-0.19 \\
(1.26)\end{array}$ \\
\hline Outpatient & 6.39 & $\begin{array}{l}-1.84 \\
(1.03)\end{array}$ & $\begin{array}{l}-0.83 \\
(4.39)\end{array}$ & 14.90 & $\begin{array}{l}3.55 \\
(2.78)\end{array}$ & $\begin{array}{l}3.06 \\
(5.51)\end{array}$ & 17.98 & $\begin{array}{l}-1.39 \\
(2.28)\end{array}$ & $\begin{array}{l}-3.30 \\
(10.92)\end{array}$ \\
\hline Medicine & 12.39 & $\begin{array}{l}-2.84^{* *} \\
(0.99)\end{array}$ & $\begin{array}{l}-27.71^{* *} \\
(13.72)\end{array}$ & 12.69 & $\begin{array}{l}0.23 \\
(0.38)\end{array}$ & $\begin{array}{l}6.19 \\
(10.50)\end{array}$ & 21.90 & $\begin{array}{l}-10.66^{* *} \\
(5.15)\end{array}$ & $\begin{array}{l}-38.58^{* * *} \\
(13.40)\end{array}$ \\
\hline \multicolumn{10}{|c|}{ A.2 Catastrophic medical expenditures (rate) } \\
\hline Total & 45.12 & $\begin{array}{l}-0.07^{*} \\
(0.04)\end{array}$ & & 56.43 & $\begin{array}{l}-0.05 \\
(0.08)\end{array}$ & & 72.14 & $\begin{array}{l}-0.11^{* *} \\
(0.05)\end{array}$ & \\
\hline \multicolumn{10}{|c|}{ B.1 Consumption } \\
\hline Total & 141.80 & $\begin{array}{l}4.04 \\
(2.59)\end{array}$ & $\begin{array}{l}3.65^{*} \\
(1.63)\end{array}$ & 116.11 & $\begin{array}{l}3.75 \\
(5.15)\end{array}$ & $\begin{array}{l}2.13 \\
(2.21)\end{array}$ & 112.75 & $\begin{array}{l}3.77 \\
(3.08)\end{array}$ & $\begin{array}{l}6.33^{*} \\
(2.67)\end{array}$ \\
\hline Food & 82.15 & $\begin{array}{l}-1.06 \\
(0.93)\end{array}$ & $\begin{array}{l}0.35 \\
(0.20)\end{array}$ & 69.32 & $\begin{array}{l}0.03 \\
(1.60)\end{array}$ & $\begin{array}{l}0.30 \\
(0.25)\end{array}$ & 71.15 & $\begin{array}{l}0.45 \\
(0.20)\end{array}$ & $\begin{array}{l}0.51 \\
(0.26)\end{array}$ \\
\hline Non-food & 49.05 & $\begin{array}{l}2.75^{*} \\
(1.45)\end{array}$ & $\begin{array}{l}3.30^{* * * *} \\
(1.45)\end{array}$ & 36.99 & $\begin{array}{l}1.18 \\
(1.56)\end{array}$ & $\begin{array}{l}1.83 \\
(1.98)\end{array}$ & 34.95 & $\begin{array}{l}3.38^{*} \\
(0.72)\end{array}$ & $\begin{array}{l}5.93^{* * *} \\
(2.43)\end{array}$ \\
\hline \multicolumn{10}{|c|}{ B.2 Consumption poverty level } \\
\hline Rate & 31.80 & $\begin{array}{l}0.02 \\
(0.10)\end{array}$ & & 46.21 & $\begin{array}{l}0.01 \\
(0.08)\end{array}$ & 0.02 & 61.53 & $\begin{array}{l}0.08 \\
(0.05)\end{array}$ & \\
\hline Households & 3,718 & & & 1,073 & & & 881 & & \\
\hline EA (cluster) & 520 & & & 447 & & & 378 & & \\
\hline
\end{tabular}

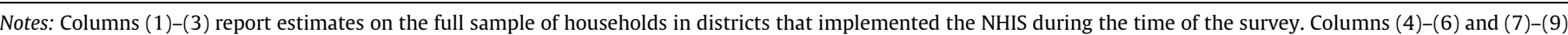

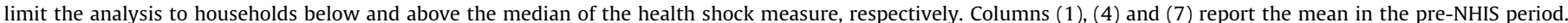

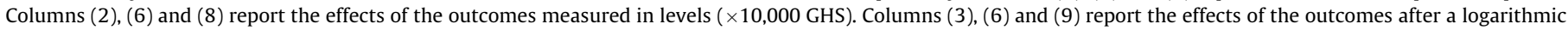

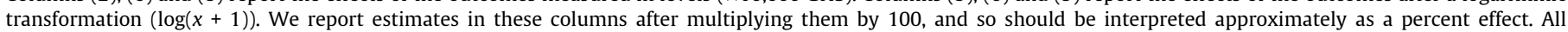

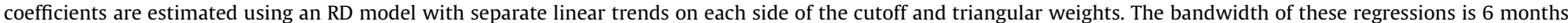

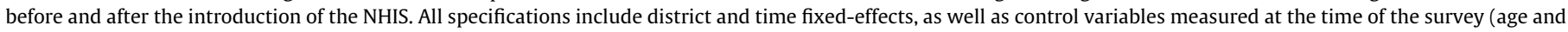

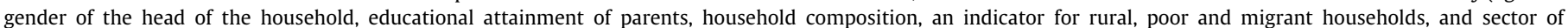
employment of the head). Standard errors in parentheses are clustered at the EA level. $* * * p<0.01, * * p<0.05, * p<0.10$.

1 US\$ 9,259 GHS in 2006.

poverty line and 0 otherwise. We do not find significant estimates of the NHIS implementation on the incidence of consumption poverty.

Our results indicate that a fraction of the estimated savings in medical out-of-pocket payments were used for higher non-food consumption among households experiencing a relatively large health shock. In what follows, we will evaluate how the remaining savings in medical expenditures shaped households' behavior.

\subsection{Coping mechanisms}

\subsubsection{Loans and remittances}

We begin our analysis on how the introduction of a public health insurance scheme impacts coping strategies by exploring loans and remittances. Both borrowing and remittances have been shown to be key instruments to cover liquidity shortages (see among others, Morduch (1995), Chetty and Looney (2006), Islam 
and Maitra (2012), Strupat and Klohn (2018)). The introduction of a public health insurance scheme would reduce the need to rely on these instruments to cope with the financial consequences of a health shock.

The RD graphs in Panels A and B of Fig. 3 show the (residualized) borrowing of households through loans and the reception of remittances. Our first observation is the higher incidence of remittances over borrowing through loans: while only $2 \%$ of households borrowed loans before the NHIS, around $20 \%$ of households were receiving remittances. ${ }^{24}$ This is in line with previous work showing that obtaining credit from formal lenders is a less direct way to obtain financing in the face of a health shock than receiving money from family or friends (Islam and Maitra, 2012). We do observe a jump at the discontinuity in the incidence of borrowing from introduction of the NHIS. This jump, however, is not statistically significant. Furthermore, the NHIS does not decrease the amount borrowed, as shown in the top right graph. We instead observe a clear drop in the incidence of remittances post-NHIS. The amount of remittances received also decreases after the NHIS, although the difference at the discontinuity is not statistically significant.

Turning to the regression results, Panels A and B in Table 3 show the estimated effects corresponding to the RD graphs. The estimates are negative for both the rate and amount of loans and remittances. The effect on the incidence of remittances is statistically significant at the 10 percent level, but this does not translate into lower remittances. In the more sickness sample, both the incidence (by 2.2 percentage points, or $6 \%$ ) and amount of received remittances (by almost US\$5) decrease significantly due to the NHIS implementation.

\subsubsection{Adult labor supply}

We now analyse intra-household labor supply as a potential source of insurance (Dercon, 2002; Gertler and Gruber, 2002). To that end, we observe the labor responses of the healthy adults, that is, these adults that do not report any illness or injury. Panel $C$ of Fig. 3 shows the RD graphs of their residualized employment participation and earnings. There is a drop in employment participation once crossing the cutoff (10 percent level of statistical significance). We also observe a drop in labor earnings around the time of the NHIS introduction but it is statistically insignificant. Measurement error in this variable is a common problem in developing countries and a likely explanation of the large standard errors (Meyer and Sullivan, 2003). The trend in earnings is negative after NHIS introduction, possibly indicating the greater crowding out of adult labor supply as NHIS enrolment rates increase.

Panel C in Table 3 reports respective RD estimates. We estimate a sizeable drop in employment participation of over $2 \% .{ }^{25}$ Our results are in line with health insurance crowding-out the need for other household members to increase their employment participation to cover the medical expenditures. As already observed in the $\mathrm{RD}$ graph, this drop in participation is not accompanied by significantly lower labor earnings, which are likely measured with imprecision.

\subsubsection{Costly coping mechanisms}

We close our analysis by assessing whether the introduction of a national health insurance policy can prevent the reliance on costly coping mechanisms when health shocks occur. To this end,

\footnotetext{
${ }^{24}$ Note that overall borrowing is not captured in our measure, as the questionnaire only measures borrowing through formal sources. Informal borrowing, most common in developing settings with limited access to capital markets, is thus not assessed here.

${ }^{25}$ We find no employment effects in the subsample of ill adult household members (see Table B.1 in the Appendix).
}

we consider the impact of the NHIS on human capital investments in children, in particular, schooling of children and child labor. Panels $C$ and D of Fig. 3 graphically show the RD results for the effects of the introduction of the NHIS on the incidence of child work, earnings, and on the time allocation of children (class attendance and household chores). The sample selected for this section is different than the sample used before, in that we exclude these households that have no children. The final sample is of 2,228 households. ${ }^{26}$ Upon crossing the cutoff, the rate of child labor drops. This drop is statistical insignificant. ${ }^{27}$ The RD graph for child earnings does not show any clear trend, possibly due to the low incidence of formally paid child laborers: child labor tends to be remunerated in kind (ILO, 2007). School attendance increases after the NHIS implementation. There is, however, large variation in this outcome variable. Household chores, on the other hand, neatly drop upon crossing the threshold. It is interesting to observe that the NHIS implementation affects household chores as early as the first month after the introduction.

Panel D and E in Table 3 shows the corresponding regression estimates. The effect on child labor is small and not statistically significant in the full sample. The weekly hours attending school increase by $2 \%$. Analogously, the hours spent on household chores decrease by $2 \%$.

Differences in the responses become stronger when dividing the sample by health shock intensity. The effect on child labor from introducing the NHIS is pronounced with a statistically significant decline in the incidence by 8.8 percentage points in the high sickness intensity sample. The time spent attending class increases by one hour in the same sample. The effects of the NHIS on household chores are qualitatively similar regardless of the intensity of the health shock ${ }^{28}$ When investigating the effect on earnings from child labor, we find negative but statistically insignificant effects. However, child labor earnings are commonly very imprecisely measured wherefore standard errors are expected to be large. ${ }^{29}$ Overall, these improvements in children outcomes are consistent with the introduction of the NHIS reducing households' reliance on costly selfinsurance mechanisms when facing a health shock.

\subsubsection{Aggregating the results}

To put our results in perspective, in this section, we use the estimated effects of the outcome variables in levels to get a rough sense of the magnitude of the responses in terms of consumption and use of coping mechanisms vis-a-vis the measured out-ofpocket medical savings. The objective of this aggregation exercise is to get an intuition whether our results are consistent with each other, as opposed to provide a precise decomposition analysis where one would take the estimates at face value. ${ }^{30}$

\footnotetext{
${ }^{26}$ We check whether the findings for the other outcomes change due to this sample restriction and present the estimates in Table B.2,B.3 and B.4 of the Appendix. We find similar results on all outcomes as compared to the full sample.

27 We note that the linear trend fitting the pre-NHIS data exhibits a declining trend. However, when fitting the more flexible line, such as the triangular-weighted shown in the figure, this trend is largely eliminated. This difference is likely attributable to outliers and the fact that the fitted linear trend reacts more sensitive to them. We show in the sensitivity section that adding triangular weights does yield qualitatively similar regression results.

28 Table B.2 shows that the introduction of the NHIS does not have an effect on the hours spent doing household chores for children in households not experiencing a health shock. This is reassuring to the fact that the outcome responds to the interaction of the NHIS with health shocks, giving plausibility to our interpretation.

${ }^{29}$ We also do not find any effect on schooling expenditures, which are generally very low. Results are available upon request.

${ }^{30}$ For instance, some of our outcome variables are skewed and, thus, the results should be viewed as giving a direction of the magnitudes of the effects only. That said, we can show that the magnitude of the effects is similar when using a logtransformation of the outcomes.
} 


\section{A. Loans}

Rate

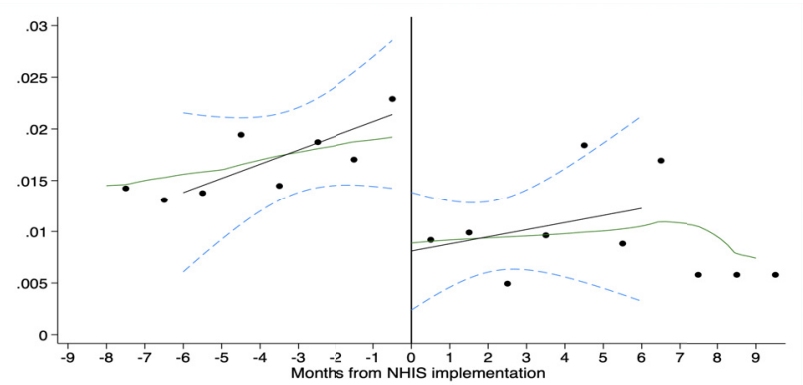

Amount

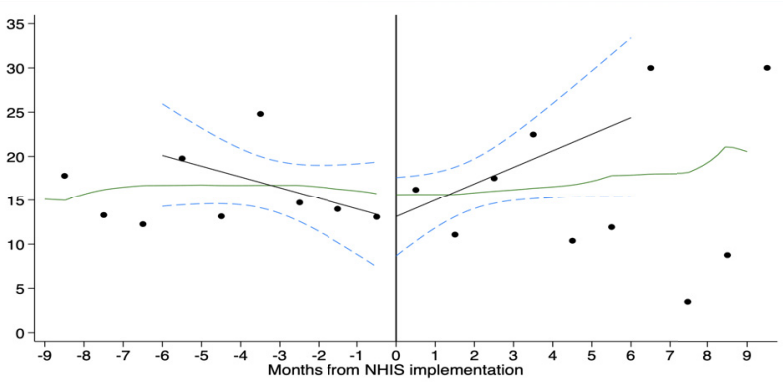

B. Remittances

Rate

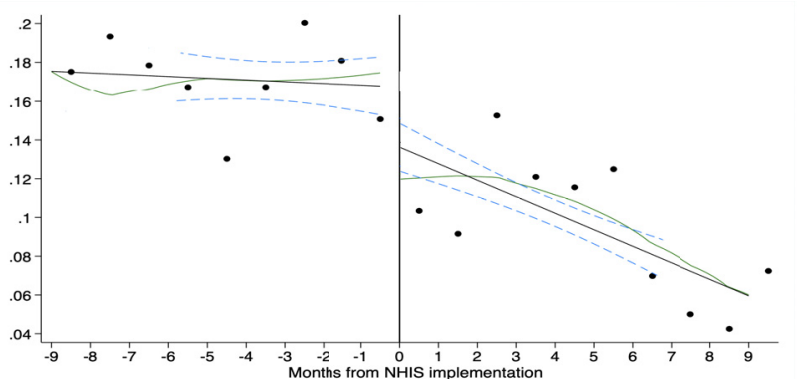

Amount

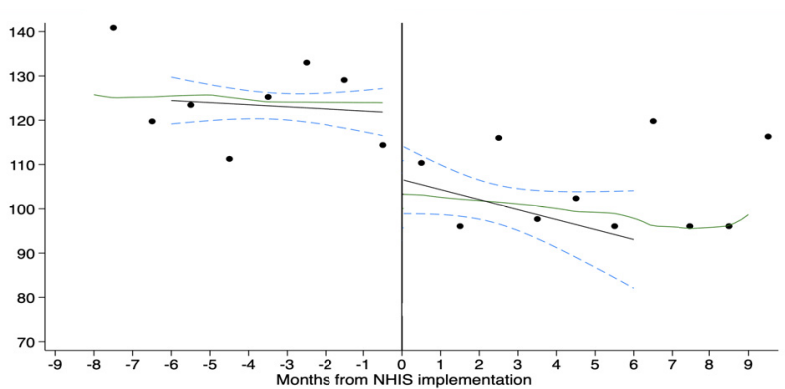

C. Adult Labor Supply

Employment

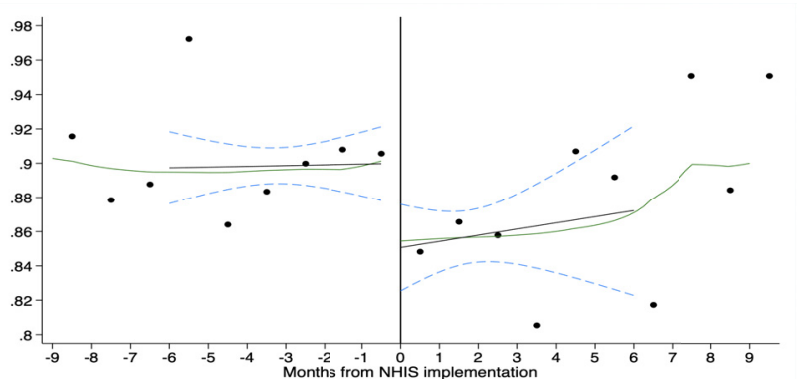

Earnings

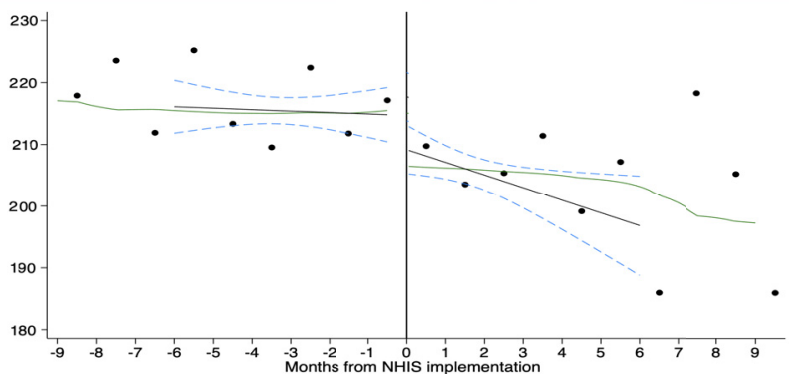

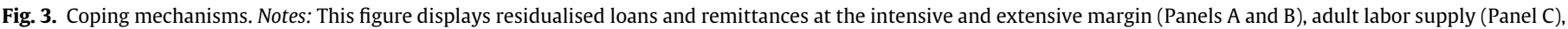

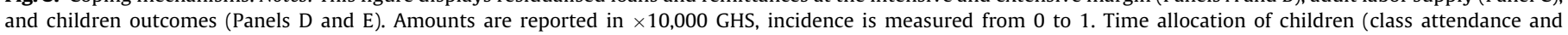
household chores) is measured in hours. See notes to Fig. 2 for more details.

In line with a marked dose-response function between health impairments and the benefits of insurance, the results for households with shorter sickness episodes are much less pronounced than for households with a more sickness intensity. We find for households experiencing health shocks with more sickness intensity that medical expenditures decrease by approximately US $\$ 13$. Out of these savings, about US $\$ 4$ sustain the increase in non-food expenditures. In addition, the savings allow for a drop in remittances received of roughly US\$5. Consistent with the idea that the remaining savings go to a combination of lower earnings from adults and children, we find negative and statistically significant impacts on both adult employment and child labor. We also find a drop in earnings, but the estimated effects are neither significant for adults nor for children. One likely reason for statistical insignificance is that earnings measures from survey data are often subject to large measurement errors (Meyer and Sullivan, 2003), which tend to bias the results towards zero. Another reason is that labor earnings, in particular the earnings of children, are partially remunerated in-kind (ILO, 2007). Indeed, children can work as contributing family members within households in our context (GLSS, 2014) and can protect food consumption levels by additional labor increasing the share of self-produced food. ${ }^{31}$

To further improve our understanding of magnitudes of the effects reported in this paper, we compare our findings with those reported in other studies. In terms of effects on out-of-pocket pay-

\footnotetext{
31 While the earning measure does not take into account the value resulting from self-production, the food expenditure measure in our analysis does. Thus, the effects of NHIS on self-production are reflected in the analysis of food consumption responses but not in the analyses of the impacts on earnings.
} 


\section{Child labor}

Child work

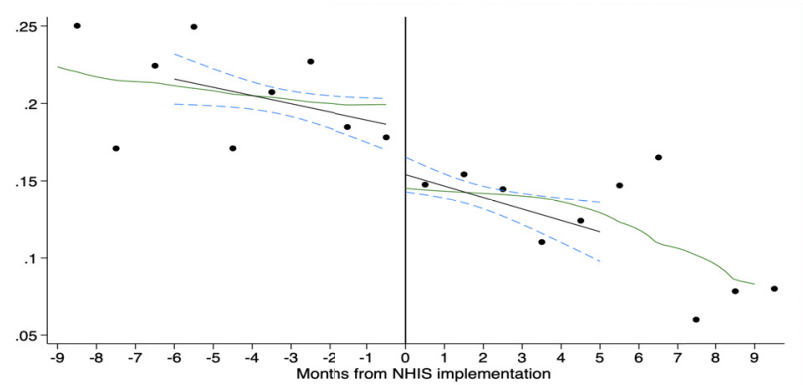

Earnings

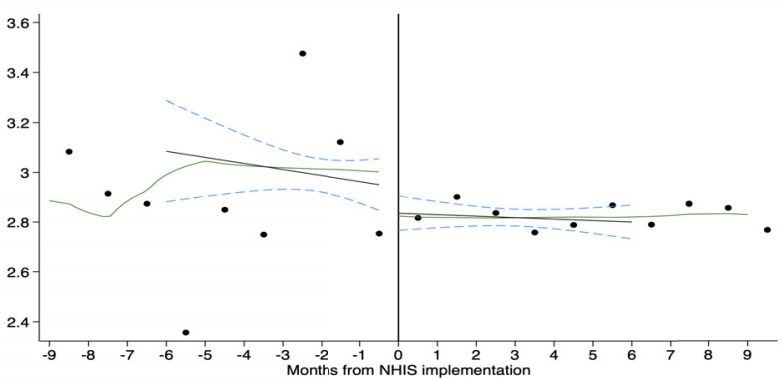

E. Time allocation of children

Class attendance

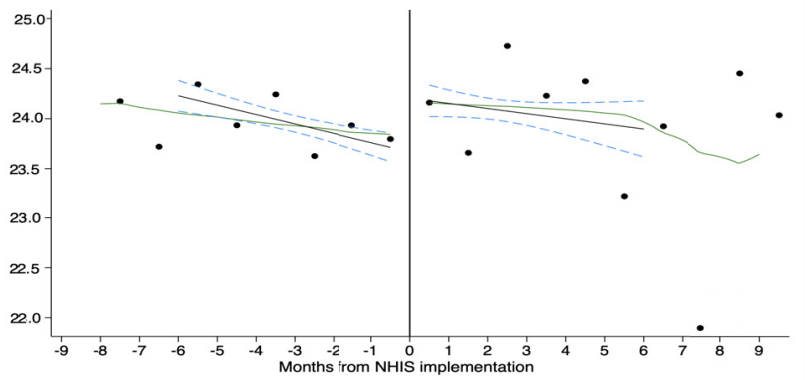

Household chores

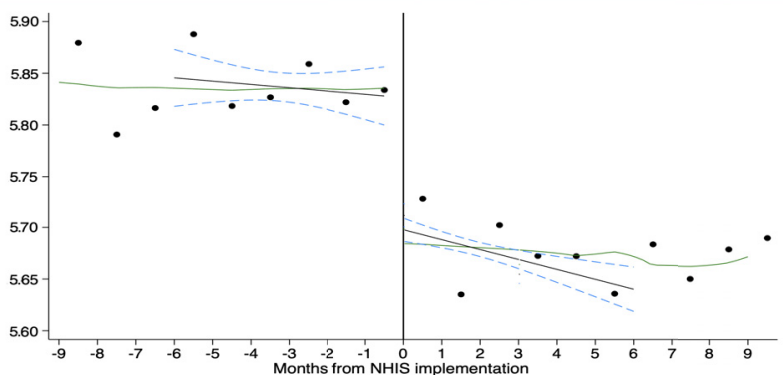

Fig. 3 (continued)

ments, our point estimate falls in the lower range of several studies estimating the effect of comprehensive health coverage (Wagstaff, 2010; Limwattananon et al., 2015). In these studies, enrolment rates were considerably higher (with more than $60 \%$ of the eligible population being enrolled). Similarly, our estimated effects on child labor in the full sample fall short relative to Landmann and Frölich (2015) who also report very high enrolment rates. King et al. (2009), on the contrary, report estimates for the effects on out of pocket payments that are relatively close to ours. The authors find a drop in out-of-pocket payments of about $23 \%$ from the introduction of the public health insurance scheme in Mexico which had an enrolment rate of roughly $45 \%$. All in all, this comparison to other studies suggests that the enrolment rate in our setting was likely below $50 \%$, with a lower bound of $20 \%$ as suggested by potentially under-reported statistics provided in NHIA (2010) (see also Section 2).

\subsection{Sensitivity}

We conduct several robustness checks to assess the sensitivity of our findings. We describe in brevity the tests below, and refer the reader to Tables B.2, B.3 and B.4 in Appendix B.

Triangular weights. As we have presented the triangular kernel-weighted local polynomial fit in all figures of our RD design, we also use this weight in our regression analysis. Observations that are nearer the cutoff receive greater weight, which yields similar results to our main specification (Row B of the sensitivity tables).

Bandwidth choice. When using a 4 and 5 month bandwidth, we obtain results that are consistent with those from our main specification (Rows $C$ and D of the sensitivity tables). This sensitivity check result speaks against a large possibility that the findings reported throughout this paper are an artefact of misspecification error and under-estimated standard errors as a result of the discreteness of our running variable, respectively (Kolesár and Rothe, 2018). ${ }^{32}$

Clustering. While Kolesár and Rothe (2018) recommend clustering at the level of treatment assignment, as we do in the main part of the paper, we find that our results are robust to more traditional ways of clustering. Specifically, we observe similar results when standard errors are clustered by the running variable interacted with the month of NHIS introduction (Row E of the sensitivity tables). ${ }^{33}$ If anything, our baseline approach produces more conservative inference. We also test that the results are consistent to clustering at the running variable, district level, and at the interaction between the date of implementation of the NHIS and date of our survey (not reported, results available upon request).

Randomization inference. Since the size of the estimation sample is relatively small, we check the robustness of our results to a randomization inference test. This test allows the proper inference in context of small samples, stratified or clustered treatment assignments, or nonstandard randomization techniques (Heß, 2017). The resulting significance levels of the point estimates are

\footnotetext{
32 Reducing the bandwidth implies a decline in the number of clusters which causes a downward bias of the cluster-robust variance in settings with a few clusters. Yet, in our case, the standard errors reported for different bandwidths do not seem to systematically differ which supports our previous argumentation that the number of clusters is sufficiently large in our analysis (see Section 4).

${ }^{33}$ We aim to group together EAs that are more similar than others even though they all belong to the same bin (i.e., same value of the running variable) by using this interaction term. The month of the NHIS introduction is arguably very useful in this regard because EAs can be observed at very different points in time and are therefore likely be quite different from one another (e.g., exposed to different temporary shocks).
} 
Table 3

RD estimates effects of NHIS introduction on coping mechanisms against health shocks.

\begin{tabular}{|c|c|c|c|c|c|c|c|c|c|}
\hline & \multicolumn{3}{|c|}{ Full Sample } & \multicolumn{3}{|c|}{ Less Sickness } & \multicolumn{3}{|c|}{ More Sickness } \\
\hline & Mean & Level & Logarithm $\log (x+1)$ & Mean & Level & Logarithm $\log (x+1)$ & Mean & Level & Logarithm $\log (x+1)$ \\
\hline & $(1)$ & $(2)$ & (3) & (4) & (5) & (6) & (7) & (8) & (9) \\
\hline \multicolumn{10}{|l|}{ A. Loans } \\
\hline Rate & 1.95 & $\begin{array}{l}-0.53 \\
(1.78)\end{array}$ & & 3.80 & $\begin{array}{l}-0.56 \\
(1.30)\end{array}$ & & 3.70 & $\begin{array}{c}0.15 \\
(0.93)\end{array}$ & \\
\hline Amount & 24.01 & $\begin{array}{l}-1.49 \\
(3.56)\end{array}$ & $\begin{array}{l}-8.95 \\
(9.32)\end{array}$ & 23.98 & $\begin{array}{c}-7.41 \\
(11.46)\end{array}$ & $\begin{array}{l}-2.57 \\
(1.71)\end{array}$ & 30.05 & $\begin{array}{c}-5.98 \\
(11.44)\end{array}$ & $\begin{array}{l}-2.79^{* * * *} \\
(1.29)\end{array}$ \\
\hline \multicolumn{10}{|c|}{ B. Remittances } \\
\hline Rate & 18.33 & $\begin{array}{c}-1.18^{*} \\
(0.68)\end{array}$ & & 19.44 & $\begin{array}{l}-2.08 \\
(1.36)\end{array}$ & & 35.37 & $\begin{array}{l}-2.24^{* *} \\
(1.00)\end{array}$ & \\
\hline Amount & 118.21 & $\begin{array}{l}-4.13 \\
(2.39)\end{array}$ & $\begin{array}{l}-2.91 \\
(2.21)\end{array}$ & 125.45 & $\begin{array}{l}-4.27 \\
(3.34)\end{array}$ & $\begin{array}{c}-4.72 \\
(23.13)\end{array}$ & 201.45 & $\begin{array}{l}-4.63^{*} \\
(3.05)\end{array}$ & $\begin{array}{l}-2.89^{* *} \\
(1.43)\end{array}$ \\
\hline \multicolumn{10}{|c|}{ C. Adult labor supply } \\
\hline Employment & 85.72 & $\begin{array}{c}-2.17 * \\
(1.14)\end{array}$ & & 86.39 & $\begin{array}{l}-2.54 \\
(2.26)\end{array}$ & & 87.57 & $\begin{array}{c}-5.71^{*} \\
(2.97)\end{array}$ & \\
\hline Earnings & 147.15 & $\begin{array}{l}-13.36 \\
(11.77)\end{array}$ & $\begin{array}{l}-2.53 \\
(4.05)\end{array}$ & 124.49 & $\begin{array}{l}-1.39 \\
(3.70)\end{array}$ & $\begin{array}{c}1.23 \\
(3.70)\end{array}$ & 330.37 & $\begin{array}{l}-15.26 \\
(46.45)\end{array}$ & $\begin{array}{l}-3.50 \\
(6.60)\end{array}$ \\
\hline $\begin{array}{l}\text { Households } \\
\text { EA (cluster) }\end{array}$ & $\begin{array}{c}3,718 \\
520\end{array}$ & & & $\begin{array}{c}1,073 \\
447\end{array}$ & & & $\begin{array}{l}881 \\
378\end{array}$ & & \\
\hline \multicolumn{10}{|l|}{ D. Child labor } \\
\hline Rate & 18.08 & $\begin{array}{l}-1.02 \\
(6.46)\end{array}$ & & 18.78 & $\begin{array}{l}-0.27 \\
(8.69)\end{array}$ & & 36.36 & $\begin{array}{l}-8.00^{* *} \\
(3.79)\end{array}$ & \\
\hline Earnings & 2.95 & $\begin{array}{l}-1.10 \\
(1.67)\end{array}$ & $\begin{array}{l}-1.33 \\
(1.95)\end{array}$ & 4.82 & $\begin{array}{l}-0.89 \\
(1.61)\end{array}$ & $\begin{array}{l}-0.30 \\
(1.43)\end{array}$ & 9.91 & $\begin{array}{l}-1.19 \\
(4.28)\end{array}$ & $\begin{array}{l}-2.57 \\
(3.20)\end{array}$ \\
\hline \multicolumn{10}{|c|}{ E. Children time allocation } \\
\hline HH Chores & 5.85 & $\begin{array}{c}-0.33^{* * *} \\
(0.11)\end{array}$ & $\begin{array}{c}-1.59^{* *} \\
(0.70)\end{array}$ & 5.23 & $\begin{array}{c}-0.32^{* * * *} \\
(0.10)\end{array}$ & $\begin{array}{c}-1.77^{* *} \\
(0.64)\end{array}$ & 7.18 & $\begin{array}{c}-0.51^{* *} \\
(0.22)\end{array}$ & $\begin{array}{l}-2.78^{* *} \\
(1.26)\end{array}$ \\
\hline School & 23.01 & $\begin{array}{c}0.58^{*} \\
(0.33)\end{array}$ & $\begin{array}{l}1.95^{* *} \\
(0.92)\end{array}$ & 23.89 & $\begin{array}{c}0.49 \\
(0.31)\end{array}$ & $\begin{array}{l}1.53^{* *} \\
(0.76)\end{array}$ & 19.66 & $\begin{array}{c}1.01^{*} \\
(0.39)\end{array}$ & $\begin{array}{l}2.59^{* *} \\
(0.96)\end{array}$ \\
\hline Households & 2,228 & & & 619 & & & 597 & & \\
\hline EA (cluster) & 516 & & & 368 & & & 311 & & \\
\hline
\end{tabular}

Notes: See notes in Table 2.

fully consistent to those reported in the main section of the paper (Row $\mathrm{F}$ of the sensitivity tables).

No control variables. We include control variables in our main specification as there are some minor imbalances across pre- and post-NHIS samples (see Table 1). However, our results are fully consistent to removing all control variables from the regression equation (Row $\mathrm{G}$ of the sensitivity tables).

Sample selection. We impose the same sample restriction used for children outcomes in all regressions. That is, we restrict the analysis to households with children. We observe some differences in the magnitude relative to the point estimates obtained for households with and without children (Row $\mathrm{H}$ of the sensitivity tables). This especially applies to the full sample, which is not split by health shock intensity. Nevertheless, removing childless households does not alter the inference and main conclusions reported in the previous section.

Alternative health shock measures. In order to explore whether our results change if we use different health shock measures, we define two different indicators. First, we take the ratio of the weighted sum of the days that every adult in the household reported having their activities of daily living (ADL) limited by an illness or injury. ${ }^{34}$ Just as with the sample divided by our sickness

\footnotetext{
${ }^{34}$ Analogous to the previous measure, we construct:

$A D L_{h t s}=\frac{\sum_{i=1}^{I} a d l_{i h t s}}{14 n_{h}}$,

where adl are the days individual $i$ from household $h$ has reported a limitation on their ADL due to sickness, over the two weeks before the interview.The median limitation ratio of illnesses over all household members is 0.07 . Accordingly, we classify households in which less than 7 percent of the days in the last two weeks were affected by an ADL limiting illness as low ADL limited households.
}

intensity measure, we find that the responses to the NHIS are concentrated among households with more ADL limitations (see Row I of the sensitivity Tables B.3 and B.4). For these households, the NHIS entailed a large drop in medical payments. We must note that the samples are much smaller (459 households for less sickness sample and 404 households for more sickness sample), since a smaller fraction of households reported ADL limitations in the survey. This explains the larger standard errors and relatively pronounced discrepancies when using the log as opposed to the level of variables. Notwithstanding, the results are similar to the results of our standard measure and confirm that the NHIS has a greater impact among households with more severe health shocks.

The second health shock variable follows our standard measure, but identifies households that lost at least one week (over the two weeks before the interview) due to sickness as being exposed to a health shock. While this measure is relatively more straightforward to interpret, the estimates rely on a small sample of 264 households. We find very large effects on medical payments, an increase in consumption (from non-food consumption), a sizeable drop in remittances and an improvement in children outcomes (see Row J of Table B.4). The point estimates tend to be larger than when using our standard health shock measure. This is evidence in support of the hypothesis that the NHIS had a greater impact on households with more severe health shocks, i.e., a dose response function between sickness intensity and avoidance of means of consumption smoothing as a result of insurance. ${ }^{35}$

\footnotetext{
${ }^{35}$ Consistent with this, when limiting our sample to households that have not experienced any health shock, we find no statistically significant effects of the NHIS on the various outcomes of interest (see Row I of B.2).
} 


\section{Conclusion}

In this paper, we exploit the fact that the implementation of the NHIS overlapped with the roll-out of the fifth round of the GLSS. We are able to observe, within the same district, enumeration areas (EAs) interviewed right before the NHIS introduction, and EAs interviewed right after. Because the timing of the interview was external to the timing of the NHIS adoption, we argue that, within the same district, whether a household was observed before or after the NHIS implementation was as good as random. We exploit this variation using a regression discontinuity design, where the running variable was the months' from the NHIS implementation at the district level.

Our results suggest that the introduction of the national health insurance have induced savings in healthcare expenditures, particularly from expenditures in medicines. Decreased out-of-pocket payments have translated into greater non-food frequent consumption and a drop in received remittances. Our results suggest that these responses from NHIS implementation were larger for households that experienced a relatively large health shock. For these households, in addition, we find an increase in class attendance and a drop in child labor. This could be indicative that households experiencing severe health shocks refrained from reducing their investments in human capital of children. Avoidance of these costly self-insurance mechanisms is potentially an important part of the social value of formal health insurance.

\section{Appendix A. Additional descriptives}

Fig. A.1 and Tables A.1-A.3.

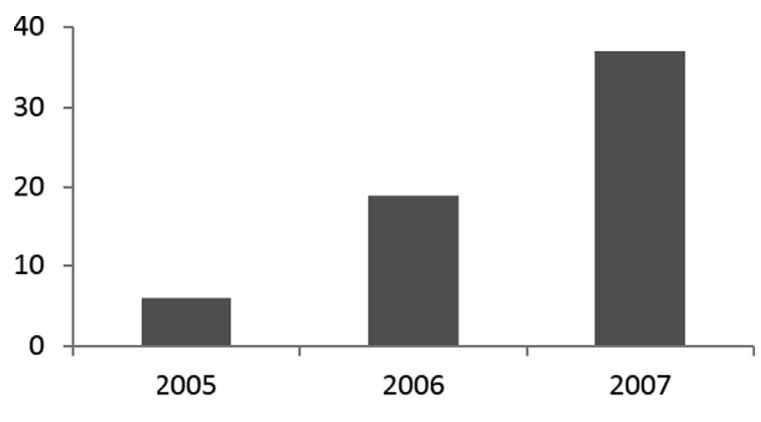

- Percentage of population enrolled with the NHIS

Fig. A.1. NHIS Enrolment Rate. Source:NHIA (2010).

Table A.1

Variable definitions.

\begin{tabular}{|c|c|c|c|}
\hline Variable & Survey question & Selection criteria & $\begin{array}{l}\text { Timing and } \\
\text { Units }\end{array}$ \\
\hline \multicolumn{4}{|l|}{ I. Health outcomes } \\
\hline Outpatient expenditures & Outpatient expenditures paid by the household & $\begin{array}{l}\text { Household outpatient expenses related to } \\
\text { illness/injury over the past two weeks }\end{array}$ & $\begin{array}{l}\text { GHS, over the } \\
\text { past two weeks; }\end{array}$ \\
\hline Inpatient expenditures & Inpatient expenditures paid by the household & $\begin{array}{l}\text { Household inpatient expenses related to } \\
\text { illness/injury over the past two weeks }\end{array}$ & $\begin{array}{l}\text { GHS, over the } \\
\text { past two weeks; }\end{array}$ \\
\hline Medicine purchases & Value of medicine purchased by the household & $\begin{array}{l}\text { Household medicine expenses related to } \\
\text { illness/injury over the past two weeks }\end{array}$ & $\begin{array}{l}\text { GHS, over the } \\
\text { past two weeks; }\end{array}$ \\
\hline $\begin{array}{l}\text { Medical out-of-pocket } \\
\text { payments }\end{array}$ & - & $\begin{array}{l}\text { Sum of household medical expenses related to } \\
\text { illness/injury over the past two weeks }\end{array}$ & $\begin{array}{l}\text { GHS, over the } \\
\text { past two weeks; }\end{array}$ \\
\hline $\begin{array}{l}\text { Catastrophic health care } \\
\text { expenditures }\end{array}$ & - & $\begin{array}{l}\text { Medical out-of-pocket payments }>10 \% \text { of the } \\
\text { income in the past two weeks }\end{array}$ & $\begin{array}{l}\text { binary, over the } \\
\text { past two weeks; }\end{array}$ \\
\hline Health shock intensity $H S$ & Days of illness/injury over the past two weeks? & $\begin{array}{l}\text { Sum of all household members days of illness/ } \\
\text { injury over the past two weeks, divided by } 14\end{array}$ & $\begin{array}{l}\text { ratio, over the } \\
\text { past two weeks; }\end{array}$ \\
\hline Less sickness & - & $\begin{array}{l}\text { Health shock intensity } \leqslant \text { median intensity } \\
\text { sample }\end{array}$ & $\begin{array}{l}\text { binary, over the } \\
\text { past two weeks; }\end{array}$ \\
\hline More sickness & - & $\begin{array}{l}\text { Health shock intensity }>\text { median intensity } \\
\text { sample }\end{array}$ & $\begin{array}{l}\text { binary, over the } \\
\text { past two weeks; }\end{array}$ \\
\hline \multicolumn{4}{|l|}{ II. Consumption } \\
\hline Food consumption & How much was spent on ... since last visit? & $\begin{array}{l}\text { Amount spent on food items by household } \\
\text { (including own produce consumption) }\end{array}$ & $\begin{array}{l}\text { GHS, over the } \\
\text { past two weeks; }\end{array}$ \\
\hline Non-food consumption & How much was spent on ... since last visit? & $\begin{array}{l}\text { Amount spent on non-food frequent } \\
\text { consumption (excluding healthcare) by } \\
\text { household }\end{array}$ & $\begin{array}{l}\text { GHS, over the } \\
\text { past two weeks; }\end{array}$ \\
\hline Consumption & - & $\begin{array}{l}\text { Amount spent on food and non-food items by } \\
\text { household }\end{array}$ & $\begin{array}{l}\text { GHS, over the } \\
\text { past two weeks; }\end{array}$ \\
\hline Poverty consumption & Is household consumption below the poverty line? & $\begin{array}{l}\text { Household daily consumption } \leqslant 44.9 \% \text { mean } \\
\text { daily consumption in Ghana }\end{array}$ & $\begin{array}{l}\text { binary, over the } \\
\text { past two weeks; }\end{array}$ \\
\hline \multicolumn{4}{|l|}{ III. Loans and remittances } \\
\hline $\begin{array}{l}\text { Remittances received for } \\
\text { health purposes }\end{array}$ & $\begin{array}{l}\text { Does this household receives or collects money or goods from any } \\
\text { other individual? Use of the cash received. }\end{array}$ & $\begin{array}{l}=1 \text { if remittances received used for health } \\
\text { purposes. }\end{array}$ & $\begin{array}{l}\text { Binary, at the } \\
\text { time of } \\
\text { interview; }\end{array}$ \\
\hline $\begin{array}{l}\text { Amount of remittances } \\
\text { received for health } \\
\text { purposes. }\end{array}$ & $\begin{array}{l}\text { What was the total amount of the cash this household received from } \\
\text { this individual during the past } 12 \text { months? Use of the cash received. }\end{array}$ & $\begin{array}{l}\text { Amount received in remittances that will be } \\
\text { primarily used for health. }\end{array}$ & $\begin{array}{l}\text { GHS, at time of } \\
\text { interview; }\end{array}$ \\
\hline Loans for health purposes & $\begin{array}{l}\text { Does any member of the household owe money or goods to another } \\
\text { person, institution, or business? Purpose of the loan. }\end{array}$ & $=1$ if money borrowed for health purposes. & $\begin{array}{l}\text { Binary, at the } \\
\text { time of } \\
\text { interview; }\end{array}$ \\
\hline $\begin{array}{l}\text { Amount of loans for } \\
\text { health purposes }\end{array}$ & What was the total amount of the original loan? Purpose of the loan. & $\begin{array}{l}\text { Amount of money borrowed for health } \\
\text { purposes. }\end{array}$ & $\begin{array}{l}\text { GHS, at the time } \\
\text { of interview; }\end{array}$ \\
\hline
\end{tabular}


Table A.2

Data sources and variable definitions (cont.).

\begin{tabular}{|c|c|c|c|}
\hline Variable & Survey question & Selection criteria & Timing and Units \\
\hline \multicolumn{4}{|c|}{ IV. Labor market supply of adults } \\
\hline Employment & Did any work in the past seven days? & $\begin{array}{l}=1 \text { if adult not experiencing a health } \\
\text { shock during the past two weeks of the } \\
\text { household responded yes }\end{array}$ & $\begin{array}{l}0 / 1 \text { dummy, over the past } \\
\text { week; }\end{array}$ \\
\hline Earnings & $\begin{array}{l}\text { Will you receive any payment for this work? } \\
\text { Amount received? }\end{array}$ & $\begin{array}{l}\text { Monetary payment received for work by } \\
\text { adult }\end{array}$ & GHS, over the past week; \\
\hline \multicolumn{4}{|l|}{ V. Children outcomes } \\
\hline Child labor & Hours worked in the past 7 days? & $\begin{array}{l}\text { = } 1 \text { if children below } 12 \text { work more than } \\
\text { one hour per week, children aged in } \\
\text { between } 12 \text { and } 13 \text { work } 14 \text { h or more, } \\
\text { and teens between } 14 \text { and } 17 \text { work more } \\
\text { than } 43 \mathrm{~h}\end{array}$ & $\begin{array}{l}0 / 1 \text { dummy, over the past } \\
\text { week; }\end{array}$ \\
\hline $\begin{array}{l}\text { Hours of household } \\
\text { chores }\end{array}$ & $\begin{array}{l}\text { Disaggregated questions on hours spent doing different } \\
\text { household chores }\end{array}$ & $\begin{array}{l}\text { Sum of all reported hours spent doing } \\
\text { household chores by children }\end{array}$ & hours, over the past week; \\
\hline Hours of class attended & How many hours of class did Name attend last week? & Hours of school attended by child & Hours, over the past week; \\
\hline Hours of homework & How many hours of homework did Name do last week? & Hours of homework done by child & Hours, over the past week; \\
\hline
\end{tabular}

Table A.3

Sample sizes by optimal bandwidth.

\begin{tabular}{|c|c|c|c|}
\hline & $\begin{array}{c}\text { Full Sample } \\
\text { (1) }\end{array}$ & $\begin{array}{c}\text { Less Sickness } \\
(2)\end{array}$ & $\begin{array}{c}\text { More Sickness } \\
\text { (3) }\end{array}$ \\
\hline \multicolumn{4}{|c|}{ Observations by Optimal Bandwidth for medical payments, consumption, loans and remittances } \\
\hline Households & 3,073 & 889 & 777 \\
\hline EA (cluster) & 430 & 369 & 326 \\
\hline$d \times$ dateNHIS (cluster) & 45 & 44 & 44 \\
\hline \multicolumn{4}{|l|}{5 months } \\
\hline Households & 3,502 & 1,009 & 843 \\
\hline EA (cluster) & 486 & 345 & 296 \\
\hline$d \times$ dateNHIS (cluster) & 53 & 52 & 52 \\
\hline \multicolumn{4}{|l|}{6 months } \\
\hline Households & 3,718 & 1,073 & 881 \\
\hline EA (cluster) & 520 & 447 & 378 \\
\hline$d \times$ dateNHIS (cluster) & 60 & 59 & 58 \\
\hline \multicolumn{4}{|c|}{ Observations by Optimal Bandwidth for children outcomes } \\
\hline Households & 2,097 & 584 & 570 \\
\hline EA (cluster) & 486 & 345 & 296 \\
\hline$d \times$ dateNHIS (cluster) & 53 & 52 & 51 \\
\hline \multicolumn{4}{|l|}{6 months } \\
\hline Households & 2,228 & 619 & 597 \\
\hline EA (cluster) & 516 & 368 & 311 \\
\hline$d \times$ dateNHIS (cluster) & 60 & 59 & 57 \\
\hline
\end{tabular}

\section{Appendix B. Additional results}

Figs. B.1 and B.2.

Tables B.1-B.4.

A. Sickness measure (HS)

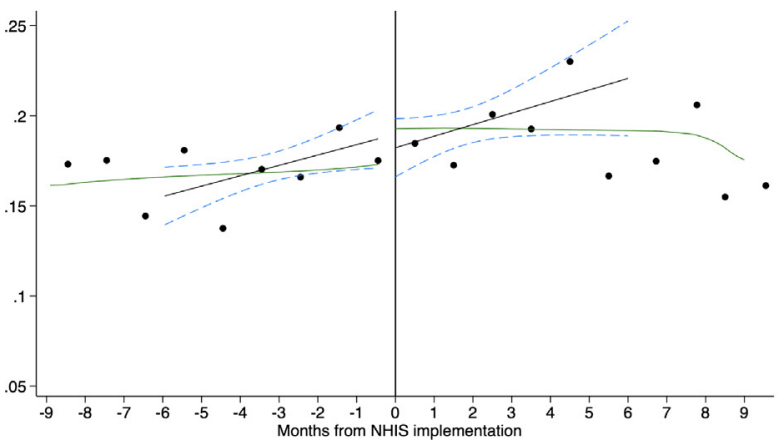

B. Probability of a highly intense sickness episode

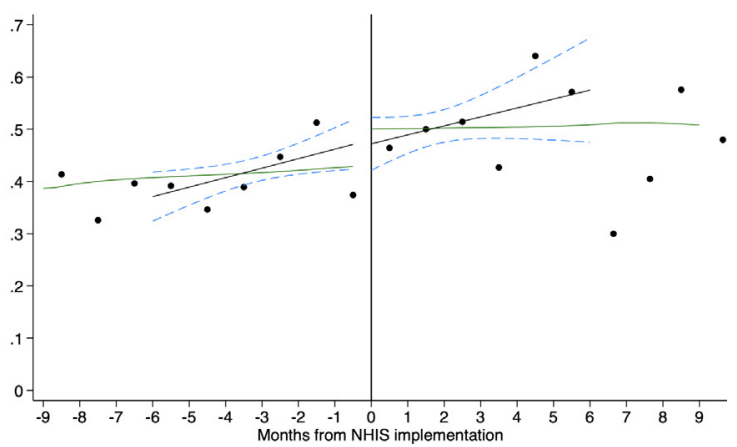

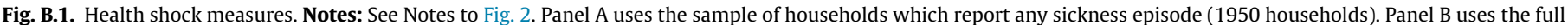
sample of households (3718 households). 
A. Components of medical out-of-pocket payments

Inpatient

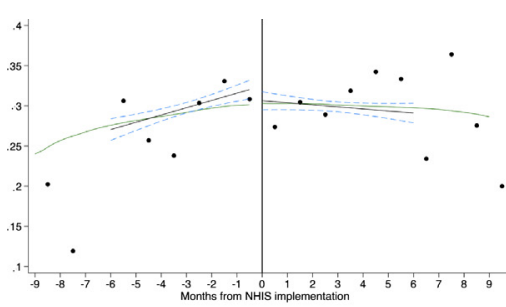

Outpatient

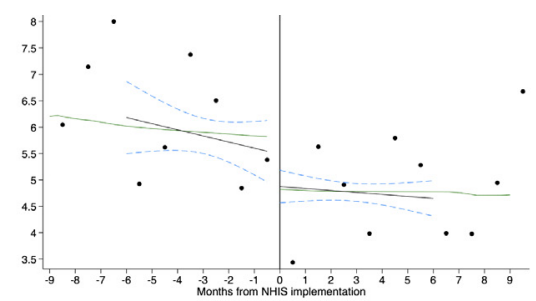

Medicine

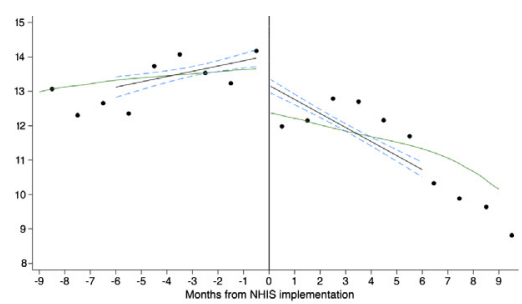

B. Components of frequent consumption

Non-food

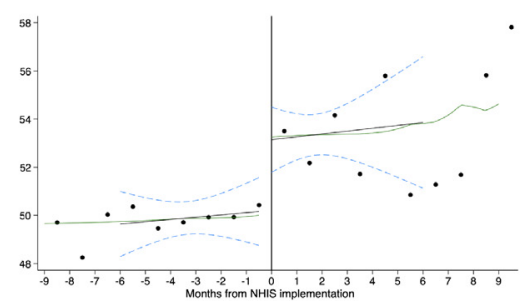

Food

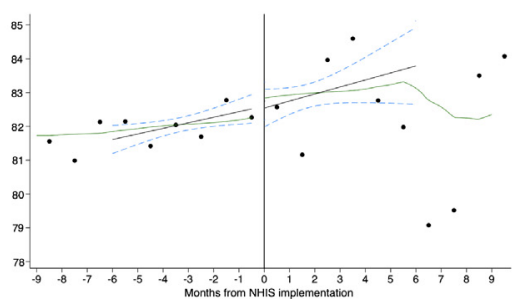

Fig. B.2. Medical expenditures and consumption (GHS, $\times 10,000)$. Notes: See Notes to Fig. 2 .

Table B.1

RD estimates effects of NHIS introduction on labor supply of ill adults.

\begin{tabular}{|c|c|c|c|c|c|c|c|c|c|}
\hline & \multicolumn{3}{|c|}{ Full Sample } & \multicolumn{3}{|c|}{ Less Sickness } & \multicolumn{3}{|c|}{ More Sickness } \\
\hline & Mean & Level & Logarithm $\log (x+1)$ & Mean & Level & Logarithm $\log (x+1)$ & Mean & Level & Logarithm $\log (x+1)$ \\
\hline & (1) & (2) & (3) & (4) & (5) & (6) & (7) & (8) & (9) \\
\hline Households & 2,179 & & & 968 & & & 1211 & & \\
\hline EA (cluster) & 553 & & & 421 & & & 498 & & \\
\hline Households & 1,852 & & & 843 & & & 1,009 & & \\
\hline EA (cluster) & 466 & & & 362 & & & 420 & & \\
\hline
\end{tabular}

Notes: See notes in Table 2. Employment coefficients are estimated with an optimal bandwidth of 7 months, and earnings of 5 months. Reported sample sizes are these of the optimal bandwidths. 
Adult labor supply

\begin{tabular}{l} 
Child labo \\
Rate \\
\hline $\mathbf{- 1 . 0 2}$ \\
$\mathbf{( 6 . 4 6 )}$ \\
-0.30 \\
$(5.33)$ \\
-0.89 \\
$(6.54)$ \\
-0.74 \\
$(6.56)$ \\
-1.02 \\
$(5.27)$ \\
-1.02 \\
{$[0.76]$} \\
-0.72 \\
$(6.71)$ \\
-1.02 \\
$(6.46)$ \\
3.45 \\
$(6.83)$
\end{tabular}

Household chores

Level Log Level Log

A. Baseline Level Log Rate

B. Triangular weights

C. BW 5 months

D. BW 4 months

E. Cluster

F. RI

$p$-value

H. No childless HH

I. No health shock

$$
\begin{aligned}
& -0.67 \\
& (1.55)
\end{aligned}
$$

\begin{tabular}{l}
\multicolumn{1}{c}{ Log } \\
\hline$-\mathbf{0 . 1 7 * *}$ \\
$(\mathbf{0 . 0 8 )}$ \\
$-0.14^{* *}$ \\
$(0.07)$ \\
$-0.16^{* *}$ \\
$(0.08)$ \\
$-0.16^{* *}$ \\
$(0.08)$ \\
$-0.17^{* * *}$ \\
$(0.05)$ \\
$-0.17^{* *}$ \\
{$[0.03]$} \\
$-0.18^{* *}$ \\
$(0.08)$ \\
$-0.21^{*}$ \\
$(0.11)$ \\
-0.02 \\
$(0.02)$
\end{tabular}

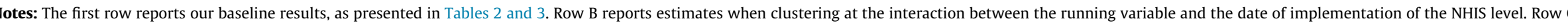

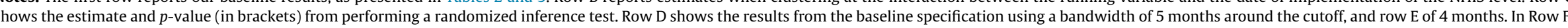
$\overrightarrow{\mathrm{v}}$ For all outcomes, log-transformed estimates should be multiplied by 100 and interpreted as percent change.

\section{Table B.3}

Sensitivity tests- Less sickness sample.

\begin{tabular}{|c|c|c|c|c|c|c|c|c|c|c|c|c|c|c|c|c|c|c|}
\hline & \multicolumn{2}{|c|}{$\begin{array}{c}\text { Medical } \\
\text { expenditures }\end{array}$} & \multicolumn{2}{|c|}{ Consumption } & \multicolumn{3}{|c|}{ Loans } & \multicolumn{3}{|c|}{ Remittances } & \multicolumn{3}{|c|}{ Adult labor supply } & \multirow{2}{*}{$\begin{array}{l}\text { Child labor } \\
\text { Rate }\end{array}$} & \multicolumn{2}{|c|}{ Household chores } & \multicolumn{2}{|c|}{$\begin{array}{c}\text { School } \\
\text { attendance }\end{array}$} \\
\hline & Level & $\log$ & Level & $\log$ & Rate & Level & $\log$ & Rate & Level & $\log$ & Rate & Level & $\log$ & & Level & $\log$ & Level & $\log$ \\
\hline A. Baseline & $\begin{array}{l}-3.79 \\
(2.94)\end{array}$ & $\begin{array}{l}-0.06 \\
(0.05)\end{array}$ & $\begin{array}{l}3.75 \\
(5.15)\end{array}$ & $\begin{array}{l}0.02 \\
(0.02)\end{array}$ & $\begin{array}{l}-0.56 \\
(1.30)\end{array}$ & $\begin{array}{l}-7.41 \\
(11.46)\end{array}$ & $\begin{array}{l}-0.03 \\
(0.02)\end{array}$ & $\begin{array}{l}-2.08 \\
(1.36)\end{array}$ & $\begin{array}{l}-4.47 \\
(3.34)\end{array}$ & $\begin{array}{l}-0.04 \\
(0.03)\end{array}$ & $\begin{array}{l}-2.54 \\
(2.26)\end{array}$ & $\begin{array}{l}-1.39 \\
(3.70)\end{array}$ & $\begin{array}{l}0.01 \\
(0.04)\end{array}$ & $\begin{array}{l}-0.27 \\
(8.69)\end{array}$ & $\begin{array}{l}-0.32 * * * \\
(0.10)\end{array}$ & $\begin{array}{l}-0.02 \\
(0.01)\end{array}$ & $\begin{array}{l}0.49 \\
(0.31)\end{array}$ & $\begin{array}{l}0.022^{* *} \\
(0.01)\end{array}$ \\
\hline B. Triangular weights & $\begin{array}{l}-1.11 \\
(2.57)\end{array}$ & $\begin{array}{l}-0.05 \\
(0.06)\end{array}$ & $\begin{array}{l}7.16 \\
(5.56)\end{array}$ & $\begin{array}{l}0.02 \\
(0.03)\end{array}$ & $\begin{array}{l}0.07 \\
(1.46)\end{array}$ & $\begin{array}{l}-13.89 \\
(18.08)\end{array}$ & $\begin{array}{l}-0.03 \\
(0.02)\end{array}$ & $\begin{array}{l}-2.27 \\
(1.33)\end{array}$ & $\begin{array}{l}-6.04 \\
(4.72)\end{array}$ & $\begin{array}{l}-0.04 \\
(0.22)\end{array}$ & $\begin{array}{l}-3.25 \\
(2.49)\end{array}$ & $\begin{array}{l}-1.10 \\
(4.18)\end{array}$ & $\begin{array}{l}0.02 \\
(0.04)\end{array}$ & $\begin{array}{l}-0.45 \\
(7.36)\end{array}$ & $\begin{array}{l}-0.29^{* *} \\
(0.12)\end{array}$ & $\begin{array}{l}-0.02 \\
(0.01)\end{array}$ & $\begin{array}{l}0.41 \\
(0.37)\end{array}$ & $\begin{array}{l}0.01 \\
(0.01)\end{array}$ \\
\hline C. BW 5 months & $\begin{array}{l}-1.18 \\
(2.43)\end{array}$ & $\begin{array}{l}-0.06 \\
(0.05)\end{array}$ & $\begin{array}{l}4.00 \\
(5.29)\end{array}$ & $\begin{array}{l}0.04 \\
(0.03)\end{array}$ & $\begin{array}{l}-0.46 \\
(1.33)\end{array}$ & $\begin{array}{l}-8.10 \\
(12.31)\end{array}$ & $\begin{array}{l}-0.03 \\
(0.02)\end{array}$ & $\begin{array}{l}-2.15 \\
(1.40)\end{array}$ & $\begin{array}{l}-4.41 \\
(3.36)\end{array}$ & $\begin{array}{l}-0.04 \\
(0.23)\end{array}$ & $\begin{array}{l}-3.84 \\
(2.38)\end{array}$ & $\begin{array}{l}-0.45 \\
(3.75)\end{array}$ & $\begin{array}{l}0.01 \\
(0.04)\end{array}$ & $\begin{array}{l}-0.30 \\
(8.69)\end{array}$ & $\begin{array}{l}-0.32 \\
(0.10)\end{array}$ & $\begin{array}{l}-0.02 \\
(0.01)\end{array}$ & $\begin{array}{l}0.49 \\
(0.31)\end{array}$ & $\begin{array}{l}0.02 \\
(0.01)\end{array}$ \\
\hline D. BW 4 months & $\begin{array}{l}-2.55 \\
(2.64)\end{array}$ & $\begin{array}{l}-0.05 \\
(0.05)\end{array}$ & $\begin{array}{l}4.37 \\
(5.52)\end{array}$ & $\begin{array}{l}-0.02 \\
(0.03)\end{array}$ & $\begin{array}{l}-0.59 \\
(1.35)\end{array}$ & $\begin{array}{l}-11.46 \\
(15.70)\end{array}$ & $\begin{array}{l}-0.03 \\
(0.02)\end{array}$ & $\begin{array}{l}-2.18 \\
(1.42)\end{array}$ & $\begin{array}{l}-4.87 \\
(3.54)\end{array}$ & $\begin{array}{l}-0.04 \\
(0.23)\end{array}$ & $\begin{array}{l}-1.23 \\
(2.37)\end{array}$ & $\begin{array}{l}-1.34 \\
(4.00)\end{array}$ & $\begin{array}{l}0.01 \\
(0.04)\end{array}$ & $\begin{array}{l}-0.24 \\
(8.80)\end{array}$ & $\begin{array}{l}-0.32 \\
(0.10)\end{array}$ & $\begin{array}{l}-0.02 \\
(0.01)\end{array}$ & $\begin{array}{l}0.51 \\
(0.31)\end{array}$ & $\begin{array}{l}0.02 \\
(0.01)\end{array}$ \\
\hline E. Cluster & $\begin{array}{l}-3.79 \\
(2.47)\end{array}$ & $\begin{array}{l}-0.06 \\
(0.05)\end{array}$ & $\begin{array}{l}3.75 \\
(5.74)\end{array}$ & $\begin{array}{l}0.02 \\
(0.02)\end{array}$ & $\begin{array}{l}-0.56 \\
(1.13)\end{array}$ & $\begin{array}{l}-7.41 \\
(9.83)\end{array}$ & $\begin{array}{l}-0.03^{*} \\
(0.01)\end{array}$ & $\begin{array}{l}-2.08 \\
(1.15)\end{array}$ & $\begin{array}{l}-4.47 \\
(3.17)\end{array}$ & $\begin{array}{l}-0.04 \\
(0.16)\end{array}$ & $\begin{array}{l}-2.54 \\
(1.89)\end{array}$ & $\begin{array}{l}-1.39 \\
(3.99)\end{array}$ & $\begin{array}{l}0.01 \\
(0.05)\end{array}$ & $\begin{array}{l}-0.27 \\
(6.84)\end{array}$ & $\begin{array}{l}-0.32 \\
(0.08)\end{array}$ & $\begin{array}{l}-0.02 \\
(0.00)\end{array}$ & $\begin{array}{l}0.49 \\
(0.32)\end{array}$ & $\begin{array}{l}0.02 \\
(0.01)\end{array}$ \\
\hline $\begin{array}{l}\text { F. RI } \\
p \text {-value }\end{array}$ & $\begin{array}{l}-3.79 \\
{[0.14]}\end{array}$ & $\begin{array}{l}-0.06 \\
{[0.18]}\end{array}$ & $\begin{array}{l}3.75 \\
{[0.41]}\end{array}$ & $\begin{array}{l}0.02 \\
{[0.33]}\end{array}$ & $\begin{array}{l}-0.56 \\
{[0.45]}\end{array}$ & $\begin{array}{l}-7.41 \\
{[0.56]}\end{array}$ & $\begin{array}{l}-0.03 \\
{[0.11]}\end{array}$ & $\begin{array}{l}-2.08 \\
{[0.11]}\end{array}$ & $\begin{array}{l}-4.47 \\
{[0.25]}\end{array}$ & $\begin{array}{l}-0.04 \\
{[0.34]}\end{array}$ & $\begin{array}{l}-2.54 \\
{[0.29]}\end{array}$ & $\begin{array}{l}-1.39 \\
{[0.52]}\end{array}$ & $\begin{array}{l}0.01 \\
{[0.74]}\end{array}$ & $\begin{array}{l}-0.27 \\
{[0.84]}\end{array}$ & $\begin{array}{l}-0.32 \\
{[0.01]}\end{array}$ & $\begin{array}{l}-0.02 \\
{[0.02]}\end{array}$ & $\begin{array}{l}0.49 \\
{[0.22]}\end{array}$ & $\begin{array}{l}0.02 \\
{[0.04]}\end{array}$ \\
\hline G. No controls & $\begin{array}{l}-3.20 \\
(3.05)\end{array}$ & $\begin{array}{l}-0.07 \\
(0.05)\end{array}$ & $\begin{array}{l}1.40 \\
(6.72)\end{array}$ & $\begin{array}{l}0.06^{* 4} \\
(0.02)\end{array}$ & $\begin{array}{l}-0.75 \\
(1.15)\end{array}$ & $\begin{array}{l}1.16 \\
(1.80)\end{array}$ & $\begin{array}{l}-0.02 \\
(0.02)\end{array}$ & $\begin{array}{l}-1.69 \\
(1.23)\end{array}$ & $\begin{array}{l}-4.98 \\
(3.31)\end{array}$ & $\begin{array}{l}-0.04 \\
(0.23)\end{array}$ & $\begin{array}{l}-2.81 \\
(2.51)\end{array}$ & $\begin{array}{l}-0.81 \\
(3.66)\end{array}$ & $\begin{array}{l}0.01 \\
(0.04)\end{array}$ & $\begin{array}{l}1.29 \\
(8.78)\end{array}$ & $\begin{array}{l}-0.30^{* *} \\
(0.12)\end{array}$ & $\begin{array}{l}-0.02 \\
(0.01)\end{array}$ & $\begin{array}{l}0.56 \\
(0.34)\end{array}$ & $\begin{array}{l}0.02^{* *} \\
(0.01)\end{array}$ \\
\hline H. No childless $\mathrm{HH}$ & $\begin{array}{l}-3.15 \\
(2.20)\end{array}$ & $\begin{array}{l}-0.07 \\
(0.06)\end{array}$ & $\begin{array}{l}-6.95 \\
(6.39)\end{array}$ & $\begin{array}{l}0.04 \\
(0.03)\end{array}$ & $\begin{array}{l}0.76 \\
(1.71)\end{array}$ & $\begin{array}{l}3.79 \\
(2.64)\end{array}$ & $\begin{array}{l}-0.03 \\
(0.03)\end{array}$ & $\begin{array}{l}-2.24 \\
(2.02)\end{array}$ & $\begin{array}{l}-6.10 \\
(6.41)\end{array}$ & $\begin{array}{l}-0.05 \\
(0.28)\end{array}$ & $\begin{array}{l}-2.46 \\
(3.06)\end{array}$ & $\begin{array}{l}1.89 \\
(6.39)\end{array}$ & $\begin{array}{l}0.00 \\
(0.05)\end{array}$ & $\begin{array}{l}-0.27 \\
(8.69)\end{array}$ & $\begin{array}{l}-0.32 \\
(0.10)\end{array}$ & $\begin{array}{l}-0.02 \\
(0.01)\end{array}$ & $\begin{array}{l}0.49 \\
(0.31)\end{array}$ & $\begin{array}{l}0.02 \\
(0.01)\end{array}$ \\
\hline I. ADL healh shock & $\begin{array}{l}-1.43 \\
(7.45)\end{array}$ & $\begin{array}{l}-0.07 \\
(0.05)\end{array}$ & $\begin{array}{l}2.03 \\
(9.32)\end{array}$ & $\begin{array}{l}0.06^{*} \\
(0.03)\end{array}$ & $\begin{array}{l}-0.04 \\
(1.74)\end{array}$ & $\begin{array}{l}1.60 \\
(2.15)\end{array}$ & $\begin{array}{l}0.05 \\
(0.23)\end{array}$ & $\begin{array}{l}-2.23 \\
(2.01)\end{array}$ & $\begin{array}{l}-3.33 \\
(4.83)\end{array}$ & $\begin{array}{l}-0.03 \\
(0.02)\end{array}$ & $\begin{array}{l}-0.13 \\
(2.38)\end{array}$ & $\begin{array}{l}2.66 \\
(4.25)\end{array}$ & $\begin{array}{l}0.03 \\
(0.07)\end{array}$ & $\begin{array}{l}1.79 \\
(11.42)\end{array}$ & $\begin{array}{l}-0.33^{* *} \\
(0.15)\end{array}$ & $\begin{array}{l}-0.02 \\
(0.01)\end{array}$ & $\begin{array}{l}0.28 \\
(0.55)\end{array}$ & $\begin{array}{l}0.02 \\
(0.02)\end{array}$ \\
\hline
\end{tabular}

Notes: See notes to Table B.2. Sample size for row I is 681 households (353 clusters). 
Table B.4

Sensitivity tests- More sickness sample.

\begin{tabular}{|c|c|c|c|c|c|c|c|c|c|c|c|c|c|c|c|c|c|c|}
\hline & \multicolumn{2}{|c|}{$\begin{array}{c}\text { Medical } \\
\text { expenditures }\end{array}$} & \multicolumn{2}{|c|}{ Consumption } & \multicolumn{3}{|c|}{ Loans } & \multicolumn{3}{|c|}{ Remittances } & \multicolumn{3}{|c|}{ Adult labor supply } & \multirow{2}{*}{$\begin{array}{l}\text { Child labor } \\
\text { Rate }\end{array}$} & \multicolumn{2}{|c|}{ Household chores } & \multicolumn{2}{|c|}{$\begin{array}{c}\text { School } \\
\text { attendance }\end{array}$} \\
\hline & Level & $\log$ & Level & $\log$ & Rate & Level & $\log$ & Rate & Level & $\log$ & Rate & Level & $\log$ & & Level & $\log$ & Level & $\log$ \\
\hline A. Baseline & $\begin{array}{l}-11.98^{* * *} \\
(5.55)\end{array}$ & $\begin{array}{l}-0.29 * \\
(0.16)\end{array}$ & $\begin{array}{l}3.77 \\
\text { (3.08) }\end{array}$ & $\begin{array}{l}0.06 * \\
(0.03)\end{array}$ & $\begin{array}{l}0.15 \\
(0.93)\end{array}$ & $\begin{array}{l}-5.98 \\
(11.44)\end{array}$ & $\begin{array}{l}-0.03^{* * * *} \\
(0.01)\end{array}$ & $\begin{array}{l}-2.24 \\
(1.00)\end{array}$ & $\begin{array}{l}-4.63^{*} \\
(3.05)\end{array}$ & $\begin{array}{l}-0.02{ }^{* *} \\
(0.01)\end{array}$ & $\begin{array}{l}-5.71^{*} \\
(2.97)\end{array}$ & $\begin{array}{l}-15.26 \\
(46.45)\end{array}$ & $\begin{array}{l}-0.03 \\
(0.07)\end{array}$ & $\begin{array}{l}-8.00^{* *} \\
(3.79)\end{array}$ & $\begin{array}{l}-0.51^{* *} \\
(0.22)\end{array}$ & $\begin{array}{l}-0.03^{* *} \\
(0.01)\end{array}$ & $\begin{array}{l}1.01^{* *} \\
(0.39)\end{array}$ & $\begin{array}{l}0.03^{* *} \\
(0.01)\end{array}$ \\
\hline B. Triangular weights & $\begin{array}{l}-12.17^{* *} \\
(5.58)\end{array}$ & $\begin{array}{l}-0.21 \\
(0.14)\end{array}$ & $\begin{array}{l}6.69 \\
(3.41)\end{array}$ & $\begin{array}{l}0.08 \\
(0.04)\end{array}$ & $\begin{array}{l}-0.12 \\
(0.92)\end{array}$ & $\begin{array}{l}-6.85 \\
(12.64)\end{array}$ & $\begin{array}{l}-0.03^{*+*} \\
(0.01)\end{array}$ & $\begin{array}{l}-2.08^{* *} \\
(0.88)\end{array}$ & $\begin{array}{l}-4.16^{*+* *} \\
(1.15)\end{array}$ & $\begin{array}{l}-0.27^{* *} \\
(0.13)\end{array}$ & $\begin{array}{l}-8.58^{* *} \\
(3.11)\end{array}$ & $\begin{array}{l}-17.67 \\
(46.08)\end{array}$ & $\begin{array}{l}-0.04 \\
(0.07)\end{array}$ & $\begin{array}{l}-7.69^{*} \\
(4.18)\end{array}$ & $\begin{array}{l}-0.41^{* *} \\
(0.19)\end{array}$ & $\begin{array}{l}-0.02^{* *} \\
(0.01)\end{array}$ & $\begin{array}{l}1.06^{* *} \\
(0.45)\end{array}$ & $\begin{array}{l}0.03^{*+*} \\
(0.01)\end{array}$ \\
\hline C. BW 5 months & $\begin{array}{l}-10.65^{* *} \\
(5.04)\end{array}$ & $\begin{array}{l}-0.29 " \\
(0.16)\end{array}$ & $\begin{array}{l}4.98 \\
(3.45)\end{array}$ & $\begin{array}{l}0.07^{13} \\
(0.03)\end{array}$ & $\begin{array}{l}0.17 \\
(0.94)\end{array}$ & $\begin{array}{l}-7.06 \\
(12.46)\end{array}$ & $\begin{array}{l}-0.03^{*+* *} \\
(0.01)\end{array}$ & $\begin{array}{l}-2.26^{* *} \\
(1.01)\end{array}$ & $\begin{array}{l}-4.00^{*} \\
(2.14)\end{array}$ & $\begin{array}{l}-0.28 \\
(0.14)\end{array}$ & $\begin{array}{l}-7.28^{* *} \\
(3.07)\end{array}$ & $\begin{array}{l}-16.95 \\
(48.03)\end{array}$ & $\begin{array}{l}-0.03 \\
(0.07)\end{array}$ & $\begin{array}{l}-7.68^{* *} \\
(3.85)\end{array}$ & $\begin{array}{l}-0.52^{* * *} \\
(0.23)\end{array}$ & $\begin{array}{l}-0.03^{* * *} \\
(0.01)\end{array}$ & $\begin{array}{l}1.00^{\prime \prime} \\
(0.40)\end{array}$ & $\begin{array}{l}0.03^{*+*} \\
(0.01)\end{array}$ \\
\hline D. BW 4 months & $\begin{array}{l}-10.35^{*} \\
(5.28)\end{array}$ & $\begin{array}{l}-0.24 \\
(0.16)\end{array}$ & $\begin{array}{l}6.05 \\
(3.83)\end{array}$ & $\begin{array}{l}0.09 \\
(0.04)\end{array}$ & $\begin{array}{l}0.26 \\
(0.95)\end{array}$ & $\begin{array}{l}-7.65 \\
(12.63)\end{array}$ & $\begin{array}{l}-0.03^{* \ldots *} \\
(0.01)\end{array}$ & $\begin{array}{l}-2.24^{* *} \\
(1.01)\end{array}$ & $\begin{array}{l}-4.70^{+* * *} \\
(1.39)\end{array}$ & $\begin{array}{l}-0.27^{*} \\
(0.14)\end{array}$ & $\begin{array}{l}-6.81^{* *} \\
(3.40)\end{array}$ & $\begin{array}{l}-24.12 \\
(53.39)\end{array}$ & $\begin{array}{l}-0.03 \\
(0.07)\end{array}$ & $\begin{array}{l}-7.27^{*} \\
(3.93)\end{array}$ & $\begin{array}{l}-0.52^{* * *} \\
(0.23)\end{array}$ & $\begin{array}{l}-0.03^{* * *} \\
(0.01)\end{array}$ & $\begin{array}{l}1.01^{\prime *} \\
(0.40)\end{array}$ & $\begin{array}{l}0.03^{*+} \\
(0.01)\end{array}$ \\
\hline E. Cluster & $\begin{array}{l}-11.98^{* * *} \\
(3.57)\end{array}$ & $\begin{array}{l}-0.29^{* * *} \\
(0.09)\end{array}$ & $\begin{array}{l}3.77 \\
(2.08)\end{array}$ & $\begin{array}{l}0.06 * \ldots \\
(0.02)\end{array}$ & $\begin{array}{l}0.15 \\
(0.77)\end{array}$ & $\begin{array}{l}-5.98 \\
(8.38)\end{array}$ & $\begin{array}{l}-0.03^{* * * *} \\
(0.01)\end{array}$ & $\begin{array}{l}-2.24^{* * *} \\
(0.56)\end{array}$ & $\begin{array}{l}-4.74 \\
(2.17)\end{array}$ & $\begin{array}{l}-0.29^{* *} \\
(0.10)\end{array}$ & $\begin{array}{l}-5.71^{*} \\
(3.41)\end{array}$ & $\begin{array}{l}-15.26 \\
(37.37)\end{array}$ & $\begin{array}{l}-0.03 \\
(0.05)\end{array}$ & $\begin{array}{l}-8.00^{*} \\
(4.50)\end{array}$ & $\begin{array}{l}-0.51^{*+*} \\
(0.17)\end{array}$ & $\begin{array}{l}-0.03^{* *} \\
(0.01)\end{array}$ & $\begin{array}{l}1.01^{* *} \\
(0.36)\end{array}$ & $\begin{array}{l}0.03 \\
0.01 \\
(0.01)\end{array}$ \\
\hline $\begin{array}{l}\text { F. RI } \\
p \text {-value }\end{array}$ & $\begin{array}{l}-11.98^{* *} \\
{[0.04]}\end{array}$ & $\begin{array}{l}-0.29^{*} \\
{[0.08]}\end{array}$ & $\begin{array}{l}3.77 \\
{[0.34]}\end{array}$ & $\begin{array}{l}0.06 \\
{[0.03]}\end{array}$ & $\begin{array}{l}0.15 \\
{[0.45]}\end{array}$ & $\begin{array}{l}-5.98 \\
{[0.56]}\end{array}$ & $\begin{array}{l}-0.03^{* * * *} \\
{[0.01]}\end{array}$ & $\begin{array}{l}-2.24^{* * * *} \\
{[0.04]}\end{array}$ & $\begin{array}{l}-4.74^{*} \\
{[0.09]}\end{array}$ & $\begin{array}{l}-0.29^{* *} \\
{[0.04]}\end{array}$ & $\begin{array}{l}-5.71^{*} \\
{[0.09]}\end{array}$ & $\begin{array}{l}-15.26 \\
{[0.46]}\end{array}$ & $\begin{array}{l}-0.03 \\
{[0.54]}\end{array}$ & $\begin{array}{l}-8.00^{* *} \\
{[0.04]}\end{array}$ & $\begin{array}{l}-0.51^{* *} \\
{[0.05]}\end{array}$ & $\begin{array}{l}-0.03^{* *} \\
{[0.02]}\end{array}$ & $\begin{array}{l}1.01^{* *} \\
{[0.02]}\end{array}$ & $\begin{array}{l}0.03^{* 4} \\
{[0.02]}\end{array}$ \\
\hline G. No controls & $\begin{array}{l}-12.94^{* *} \\
(5.94)\end{array}$ & $\begin{array}{l}-0.36^{* *} \\
(0.19)\end{array}$ & $\begin{array}{l}1.54 \\
(3.24)\end{array}$ & $\begin{array}{l}0.10 \\
0.03\end{array}$ & $\begin{array}{l}-0.32 \\
(0.94)\end{array}$ & $\begin{array}{l}-6.53 \\
(12.75)\end{array}$ & $\begin{array}{l}-0.03^{* * * *} \\
(0.01)\end{array}$ & $\begin{array}{l}-2.24^{* *} \\
(1.06)\end{array}$ & $\begin{array}{l}-4.71 \\
(3.67)\end{array}$ & $\begin{array}{l}-0.29^{* *} \\
(0.14)\end{array}$ & $\begin{array}{l}-4.48 \\
(2.92)\end{array}$ & $\begin{array}{l}-14.62 \\
(46.21)\end{array}$ & $\begin{array}{l}-0.02 \\
(0.06)\end{array}$ & $\begin{array}{l}-8.18^{* *} \\
(4.03)\end{array}$ & $\begin{array}{l}-0.41^{* *} \\
(0.18)\end{array}$ & $\begin{array}{l}-0.02 \\
(0.01)\end{array}$ & $\begin{array}{l}0.94^{4 *} \\
(0.34)\end{array}$ & $\begin{array}{l}0.02 \\
(0.01)\end{array}$ \\
\hline H. No childless HH & $\begin{array}{l}-12.89^{* *} \\
(5.60)\end{array}$ & $\begin{array}{l}-0.35 \\
(0.21)\end{array}$ & $\begin{array}{l}4.68 \\
(4.51)\end{array}$ & $\begin{array}{l}0.08 \\
(0.03)\end{array}$ & $\begin{array}{l}0.37 \\
(1.29)\end{array}$ & $\begin{array}{l}-11.68 \\
(22.33)\end{array}$ & $\begin{array}{l}-0.05^{* *} \\
(0.02)\end{array}$ & $\begin{array}{l}-3.12^{* *} \\
(1.42)\end{array}$ & $\begin{array}{l}-4.32 \\
(3.29)\end{array}$ & $\begin{array}{l}-0.39^{* *} \\
(0.19)\end{array}$ & $\begin{array}{l}-5.69^{*} \\
(3.25)\end{array}$ & $\begin{array}{l}-24.43 \\
(61.65)\end{array}$ & $\begin{array}{l}-0.04 \\
(0.09)\end{array}$ & $\begin{array}{l}-8.00^{* * *} \\
(3.79)\end{array}$ & $\begin{array}{l}-0.51^{* *} \\
(0.22)\end{array}$ & $\begin{array}{l}-0.03^{* * *} \\
(0.01)\end{array}$ & $\begin{array}{l}1.01^{* *} \\
(0.39)\end{array}$ & $\begin{array}{l}0.03^{*+} \\
(0.01)\end{array}$ \\
\hline I. ADL health shock & $\begin{array}{l}-8.12^{*} \\
(4.61)\end{array}$ & $\begin{array}{l}-0.38^{* *} \\
(0.15)\end{array}$ & $\begin{array}{l}3.03 \\
(2.31)\end{array}$ & $\begin{array}{l}0.01 \\
(0.03)\end{array}$ & $\begin{array}{l}-1.29 \\
(1.53)\end{array}$ & $\begin{array}{l}-6.41 \\
(7.27)\end{array}$ & $\begin{array}{l}-0.11 \\
(0.11)\end{array}$ & $\begin{array}{l}-3.23 \\
(1.76)\end{array}$ & $\begin{array}{l}-6.55 \\
(20.80)\end{array}$ & $\begin{array}{l}-0.04^{* * *} \\
(0.02)\end{array}$ & $\begin{array}{l}-5.61 \\
(5.02)\end{array}$ & $\begin{array}{l}-34.16 \\
(37.27)\end{array}$ & $\begin{array}{l}-0.09 \\
(0.05)\end{array}$ & $\begin{array}{l}-7.07 \\
(8.51)\end{array}$ & $\begin{array}{l}-0.57^{* * * *} \\
(0.20)\end{array}$ & $\begin{array}{l}-0.02^{* * *} \\
(0.01)\end{array}$ & $\begin{array}{l}0.55 \\
(0.36)\end{array}$ & $\begin{array}{l}0.02 \\
(0.01)\end{array}$ \\
\hline J. Severe health shock & $\begin{array}{l}-13.98^{* *} \\
(6.52)\end{array}$ & $\begin{array}{l}-0.57^{* *} \\
(0.25)\end{array}$ & $\begin{array}{l}2.44 \\
(2.02)\end{array}$ & $\begin{array}{l}0.08^{*} \\
(0.04)\end{array}$ & $\begin{array}{l}-0.63 \\
(3.54)\end{array}$ & $\begin{array}{l}-3.50 \\
(3.64)\end{array}$ & $\begin{array}{l}0.00 \\
(0.41)\end{array}$ & $\begin{array}{l}-4.59 \\
(3.45)\end{array}$ & $\begin{array}{l}-10.31 \\
(21.39)\end{array}$ & $\begin{array}{l}-0.06^{*} \\
(0.03)\end{array}$ & $\begin{array}{l}-11.28^{* *} \\
(4.98)\end{array}$ & $\begin{array}{l}-122.33 \\
(148.96)\end{array}$ & $\begin{array}{l}-0.08 \\
(0.11)\end{array}$ & $\begin{array}{l}-8.21 \\
(8.88)\end{array}$ & $\begin{array}{l}-0.74^{* * * *} \\
(0.20)\end{array}$ & $\begin{array}{l}-0.05^{* * * *} \\
(0.01)\end{array}$ & $\begin{array}{l}0.66 \\
(0.78)\end{array}$ & $\begin{array}{l}0.04^{* *} \\
(0.02)\end{array}$ \\
\hline
\end{tabular}

Notes: See notes to Table B.2. Sample size for row I is 630 households (331 clusters). Sample size for row J is 336 households (209 clusters). 


\section{References}

Agyepong, I.A., Adjei, S., 2008. Public social policy development and implementation: a case study of the Ghana national health insurance scheme. Health Policy Plan. 23 (2), 150-160.

Al-Ubaydli, O., List, J.A., LoRe, D., Suskind, D., 2017. Scaling for economists: lessons from the non-adherence problem in the medical literature. J. Econ. Perspect. 31 (4), 125-144.

Alhassan, R.K., Nketiah-Amponsah, E., Spieker, N., Arhinful, D.K., de Wit, T.F.R., 2016. Perspectives of frontline health workers on Ghana's national health insurance scheme before and after community engagement interventions. BMC Health Serv. Res. 16 (1), 192.

Bagnoli, L., 2019. Does health insurance improve health for all? Heterogeneous effects on children in Ghana. World Dev. 124, 104636.

Bauhoff, S., Hotchkiss, D.R., Smith, O., 2011. The impact of medical insurance for the poor in Georgia: a regression discontinuity approach. Health Econ. 20 (11), 1362-1378.

Beegle, K., Dehejia, R., Gatti, R., 2009. Why should we care about child labor? The education, labor market, and health consequences of child labor. J. Hum. Resour. 44 (4), 871-889.

Bergolo, M., Cruces, G., 2014. Work and tax evasion incentive effects of social insurance programs: evidence from an employment-based benefit extension. J. Public Econ. 117, 211-228.

Borga, L.G., 2019. Children's own time use and its effect on skill formation. J. Develop. Stud. 55 (5), 876-893.

Calonico, S., Cattaneo, M.D., Farrell, M.H., Titiunik, R., 2016. rdrobust: Software for regression discontinuity designs.

Cameron, A.C., Miller, D., 2015. A practitioner's guide to cluster-robust inference. J. Hum. Resour. 50 (2), 317-372.

Chetty, R., Looney, A., 2006. Consumption smoothing and the welfare consequences of social insurance in developing economies. J. Public Econ. 90 (12), 2351-2356.

Christian, P., Dillon, B., 2018. Growing and learning when consumption is seasonal: long-term evidence from Tanzania. Demography 55 (3), 1091-1118.

Cylus, J., Thomson, S., Evetovits, T., 2018. Catastrophic health spending in Europe: equity and policy implications of different calculation methods. Bull. World Health Organ. 96 (9), 599.

Debpuur, C., Dalaba, M.A., Chatio, S., Adjuik, M., Akweongo, P., 2015. An exploration of moral hazard behaviors under the national health insurance scheme in northern Ghana: a qualitative study. BMC Health Serv. Res. 15 (1), 469.

Dercon, S., 2002. Income risk, coping strategies, and safety nets. World Bank Res. Observ. 17 (2), 141-166.

Dumas, C., 2012. Does work impede child learning? The case of Senegal. Econ. Dev. Cult. Change 60 (4), 773-793.

Edmonds, E.V., 2006. Child labor and schooling responses to anticipated income in South Africa. J. Dev. Econ. 81 (2), 386-414.

Emerson, P.M., Souza, A.P., 2011. Is child labor harmful? The impact of working earlier in life on adult earnings. Econ. Dev. Cult. Change 59 (2), 345-385.

Gajate-Garrido, O., 2013. The national health insurance scheme in ghana: Implementation challenges and proposed solutions. IFPRI Discussion Paper 01309.

Gerard, F., Gonzaga, G., 2016. Informal labor and the efficiency cost of social programs: Evidence from the brazilian unemployment insurance program. CEPR Discussion Papers 11485.

Gertler, P., Gruber, J., 2002. Insuring consumption against illness. Am. Econ. Rev. 92 (1), 51-70.

Ghana, S.S., 2018. Poverty trends in ghana 2005-2017.

GLSS, 2014. Ghana living standard- labour force report.

Heady, C., 2003. The effect of child labor on learning achievement. World Dev. 31 (2), 385-398.

Heß, S., 2017. Randomization inference with stata: A guide and software. Stata J. 17 (3), 630-651.

ILO, 2007. Child labour wages and productivity: Results from demand-side surveys.

Islam, A., Maitra, P., 2012. Health shocks and consumption smoothing in rural households: does microcredit have a role to play? J. Dev. Econ. 97 (2), 232-243.

Janzen, S.A., Carter, M.R., 2019. After the drought: the impact of microinsurance on consumption smoothing and asset protection. Am. J. Agric. Econ. 101 (3), 651671.
Keane, M.P., Krutikova, S., Neal, T., 2018. The impact of child work on cognitive development: results from four low to middle income countries. Technical report. IFS Working Papers.

Khan, F., Bedi, A.S., Sparrow, R., 2015. Sickness and death: economic consequences and coping strategies of the urban poor in Bangladesh. World Dev. 72, 255-266.

King, G., Gakidou, E., Imai, K., Lakin, J., Moore, R.T., Nall, C., Ravishankar, N., Vargas, M., Téllez-Rojo, M.M., Ávila, J.E.H., Ávila, M.H., Llamas, H.H., 2009. Public policy for the poor? A randomised assessment of the mexican universal health insurance programme. Lancet 373 (9673), 1447-1454.

Kolesár, M., Rothe, C., 2018. Inference in regression discontinuity designs with a discrete running variable. Am. Econ. Rev. 108 (8), 2277-2304.

Landmann, A., Frölich, M., 2015. Can health-insurance help prevent child labor? An impact evaluation from Pakistan. J. Health Econ. 39, 51-59.

Limwattananon, S., Neelsen, S., O’Donnell, O., Prakongsai, P., Tangcharoensathien, V., Van Doorslaer, E., Vongmongkol, V., 2015. Universal coverage with supply-side reform: the impact on medical expenditure risk and utilization in Thailand. J. Public Econ. 121, 79-94.

Liu, K., 2016. Insuring against health shocks: health insurance and household choices. J. Health Econ. 46, 16-32.

McCrary, J., 2008. Manipulation of the running variable in the regression discontinuity design: a density test. J. Econometrics 142 (2), 698-714.

Meyer, B.D., Sullivan, J.X., 2003. Measuring the well-being of the poor using income and consumption. J. Hum. Resour. 38, 1180-1220.

Mitra, S., Palmer, M., Mont, D., Groce, N., 2016. Can households cope with health shocks in Vietnam?. Health Econ. 25 (7), 888-907.

Mohanan, M., 2013. Causal effects of health shocks on consumption and debt: quasi-experimental evidence from bus accident. Rev. Econ. Stat. 95 (2), $673-$ 681.

Morduch, J., 1995. Income smoothing and consumption smoothing. J. Econ. Perspect. 9 (3), 103-114.

Murray, C.J., 1996. Epidemiology and morbidity transitions in India. Health, Poverty and Development in India, pp. 122-147.

Mussa, E.C., Mirzabaev, A., Admassie, A., Nshakira-Rukundo, E., von Braun, J., 2019. Does childhood work impede long-term human capital accumulation? Empirical evidence from rural Ethiopia. Int. J. Educ. Develop. 66, 234-246.

NHIA, 2010. National Health Insurance Authority, annual report.

Otoo, K.N., Osei-Boateng, C., Asafu-Adjaye, P., 2009. The labour market in Ghana: A descriptive analysis of the labour market component of the Ghana living standards survey (v). Labour Research and Policy Institute of Ghana Trades Union Congress.

Posso, A., 2017. Child labour's effect on long-run earnings: an analysis of cohorts. Econ. Model. 64, 465-472.

Rosenzweig, M.R., Wolpin, K.I., 1993. Credit market constraints, consumption smoothing, and the accumulation of durable production assets in low-income countries: investments in bullocks in India. J. Polit. Econ. 101 (2), 223-244.

Skoufias, E., Quisumbing, A.R., 2005. Consumption insurance and vulnerability to poverty: a synthesis of the evidence from Bangladesh, Ethiopia, Mali, Mexico and Russia. Eur. J. Develop. Res. 17 (1), 24-58.

Strupat, C., Klohn, F., 2018. Crowding out of solidarity? Public health insurance versus informal transfer networks in Ghana. World Dev. 104, 212-221.

Sturrock, S., Hodes, M., 2016. Child labour in low-and middle-income countries and its consequences for mental health: a systematic literature review of epidemiologic studies. Eur. Child Adolescent Psychiatry 25 (12), 1273-1286.

Sulzbach, S., Garshong, B., Owusu-Banahene, G., 2005. Evaluating the effects of the national health insurance act in Ghana: Baseline report. Partners for Health Reformplus.

Townsend, R.M., 1994. Risk and insurance in village India. Econometrica: J. Econometric Soc., 539-591

Wagstaff, A., 2010. Estimating health insurance impacts under unobserved heterogeneity: the case of Vietnam's health care fund for the poor. Health Econ. 19 (2), 189-208.

Wagstaff, A., Flores, G., Hsu, J., Smitz, M.-F., Chepynoga, K., Buisman, L.R., van Wilgenburg, K., Eozenou, P., 2018. Progress on catastrophic health spending in 133 countries: a retrospective observational study. Lancet Glob. Health 6 (2), e169-e179.

World Bank, 2014. World development report 2014: Risk and opportunity managing risk for development. Technical report. The World Bank. 